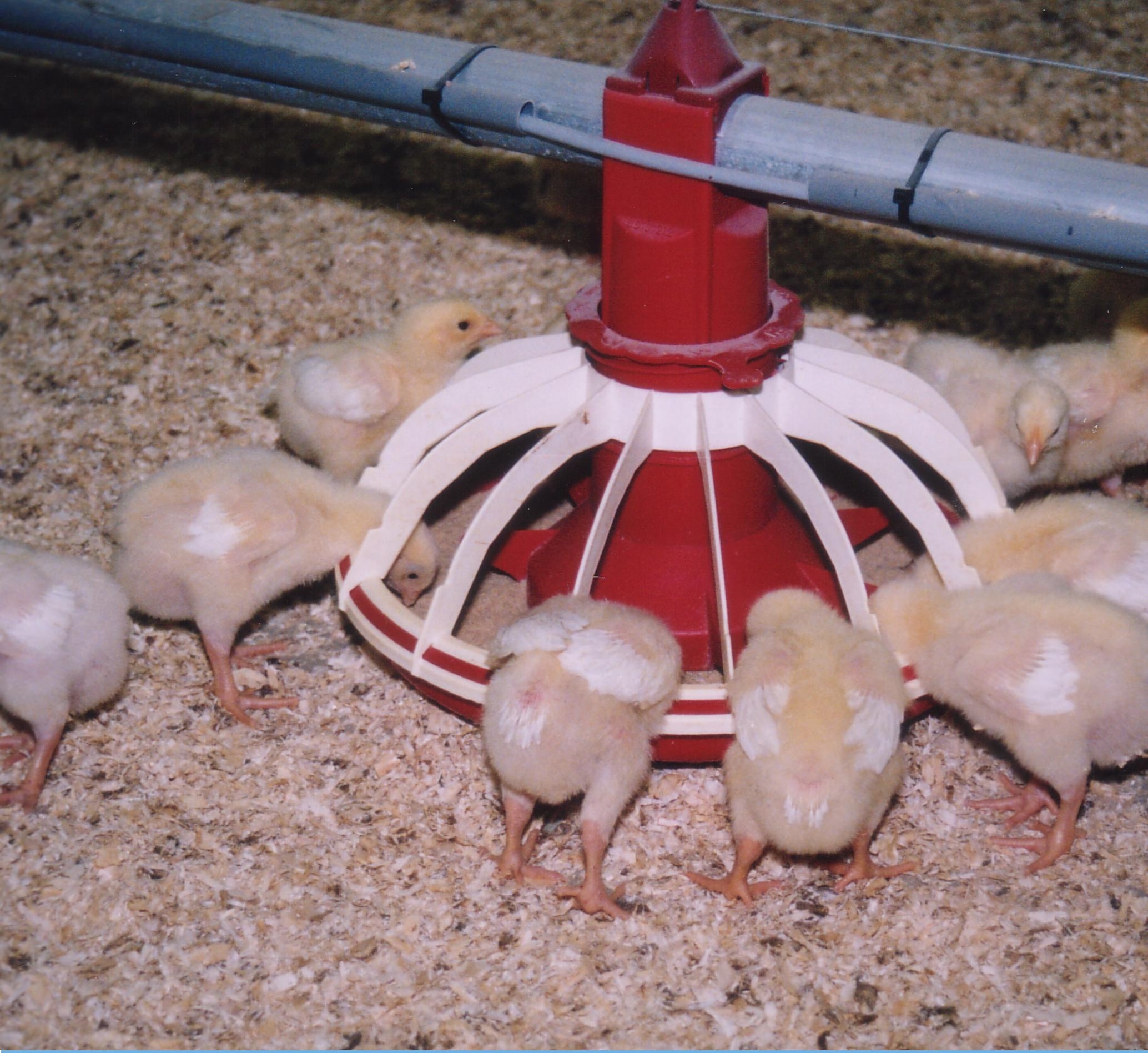

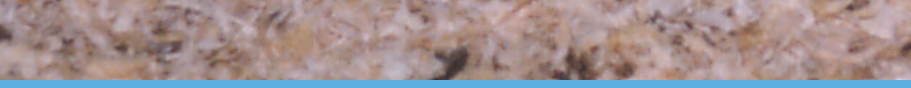

Effect of low protein diets supplemented with free amino acids on growth performance, slaughter yield, litter quality, footpad lesions, economical performance and the ecological footprint of male broilers 



\section{Effect of low protein diets supplemented with free amino acids on growth performance, slaughter yield, litter quality, footpad lesions, economical performance and the ecological footprint of male broilers}

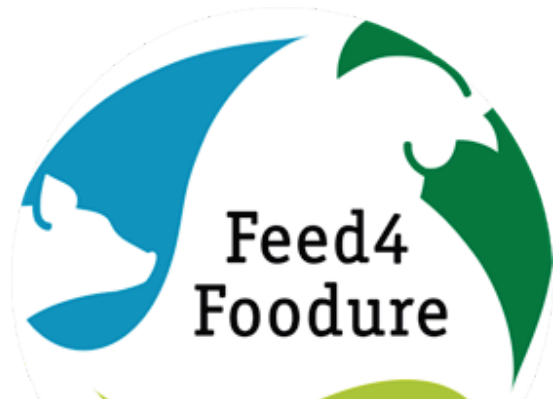

${ }^{1}$ Wageningen Livestock Research

${ }^{2}$ ForFarmers

This research was conducted by Wageningen Livestock Research, within the framework of the public private partnership "Feed4Foodure" and partially funded by the Ministry of Economic Affairs (Policy Support Research project number BO-31.03-005-00)

Wageningen Livestock Research

Wageningen, June 2017 
Harn, van J., M.A. Dijkslag and M.M. van Krimpen, 2017. Effect of low protein diets supplemented with free amino acids on growth performance, slaughter yield, litter quality, footpad lesions, economical performance and the ecological footprint of male broilers. Wageningen Livestock Research, Report 1033.

\section{Samenvatting}

Het verstrekken van voeders met een verlaagd eiwitgehalte aangevuld met vrije aminozuren om de aminozuurbehoefte van vleeskuikens te dekken kan bijdragen tot het verminderen van het gebruik van sojaschroot van Zuid Amerikaanse herkomst. Verondersteld werd dat het verstrekken van voeders met een lager eiwitgehalte de carbon footprint kan verlagen doordat minder soja in het voer verwerkt hoeft te worden. Vanuit de literatuur is bekend dat het verlagen van het eiwitgehalte in het voer, zonder dat hierbij essentiële aminozuren worden aangevuld, resulteert in een verslechtering van de dierprestaties (groei en voerefficiëntie). Het aanvullen van vleeskuikenvoeders met een verlaagd ruw eiwitgehalte met vrije aminozuren is noodzakelijk om de productieresultaten op peil te houden. Vleeskuikenvoeders worden normaliter geoptimaliseerd op minimale eisen voor verteerbaar lysine, methionine+cysteine, threonine en tryptofaan. Bij laag eiwit voeder kunnen echter ook de aminozuren valine, isoleucine, serine en glycine beperkend worden. In dit rapport worden de resultaten beschreven van een vleeskuikenstudie waarin de effecten van het verstrekken van groei- en afmestvoeders met een 10, 20 of 30 gram per kilogram verlaagd ruw eiwitgehalte ten opzichte van een controlerantsoen met een eiwitgehalte in het groei- en afmestvoer van 208 en $198 \mathrm{~g} / \mathrm{kg}$, maar met een vergelijkbaar aminozuurgehalte op de productieresultaten, slachtrendementen, strooiselkwaliteit, voetzoollaesies, economische resultaten en carbon footprint werd onderzocht.

\section{Summary}

Providing diets with a reduced crude protein $(\mathrm{CP})$ content that are supplemented with increased contents of free amino acids (AA) to cover the AA requirement might be helpful in reducing the soybean meal content of South American origin, and thus in reducing the amount of non-EU protein in the diet. For maintaining performance levels of broilers that are fed low CP diets, the AA supply is essential. Broiler diets are usually at least optimised for minimum requirements of digestible lysine, methionine + cysteine, threonine and tryptophan. In low CP diets, the requirements for the AA valine, isoleucine, serine and glycine should also be taken into account as well. The impact of using diets with a low CP content and a high amount of free AA content on the ecological footprint is not known.

This report describes the results of an experiment with male broilers in which the effect of low CP diets, with a partial replacement of soybean meal by free $A A$, on technical performance, slaughter yields, litter quality, footpad lesions, economical performance and the ecological footprint was evaluated.

This report can be downloaded for free at http://dx.doi.org/10.18174/416970 www.wur.nl/livestock-research (under Wageningen Livestock Research publications).

(C) 2017 Wageningen Livestock Research

P.O. Box 338, 6700 AH Wageningen, The Netherlands, T +31 (0)317 4839 53, E info.livestockresearch@wur.nl, www.wur.nl/livestock-research. Wageningen Livestock Research is part of Wageningen University \& Research.

All rights reserved. No part of this publication may be reproduced and/or made public, whether by print, photocopy, microfilm or any other means, without the prior permission of the publisher or author.

The ISO 9001 certification by DNV underscores our quality level. All our research commissions are in line with the Terms and Conditions of the Animal Sciences Group. These are filed with the District Court of Zwolle. 


\section{Table of contents}

$\begin{array}{ll}\text { Foreword } & 5\end{array}$

$\begin{array}{ll}\text { Summary } & 7\end{array}$

$\begin{array}{llr}1 & \text { Introduction } & 9\end{array}$

$2 \quad$ Materials and Methods $\quad 11$

2.1 Study objective $\quad 11$

2.2 Start date and end date of the experiment 11

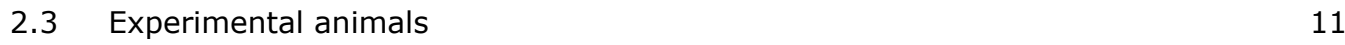

2.4 Experimental design $\quad 11$

2.5 Experimental diets 12

2.6 Animal and housing conditions 12

$\begin{array}{lll}2.7 & \text { Observations and measurements } & 14\end{array}$

$\begin{array}{lll}2.8 & \text { Statistical analysis } & 15\end{array}$

$\begin{array}{llr}3 & \text { Results } & 17\end{array}$

$\begin{array}{lll}3.1 & \text { General } & 17\end{array}$

$\begin{array}{lll}3.2 & \text { Diet analyses } & 17\end{array}$

3.3 Growth performance results 19

3.3.1 Grower phase 19

3.3.2 Finisher phase 19

3.3.3 Grower and finisher phase $\quad 20$

3.3.4 Entire experimental period $\quad 20$

$\begin{array}{lll}3.4 & \text { Slaughter yields } & 21\end{array}$

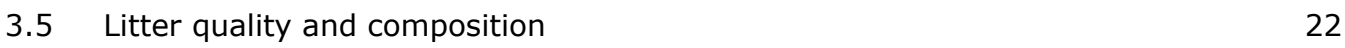

3.6 Effect of low protein diets on economic parameters and carbon footprint 22

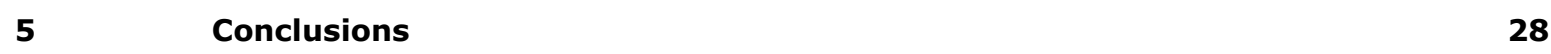

$\begin{array}{ll}\text { References } & 29\end{array}$

$\begin{array}{lll}\text { Appendix } 1 & \text { Lay-out of the experimental facility } & 31\end{array}$

Appendix 2 Feed composition and calcu-lated nutrients of the diets 32

Appendix 3 Amino acid ratios to lysine 33

Appendix 4 Overview of scores for foot-pad lesions

Appendix 5 Relative differences between calculated and analysed amino acid contents of the grower and finisher diets 35

Appendix 6 Performance results 0-11 days 36

Appendix 7 Effect diet composition on carbon footprint diet 37 



\section{Foreword}

Feed4Foodure is a public-private partnership between the Dutch Ministry of Economic Affairs, a consortium of various organizations within the animal production chain and Wageningen Livestock Research. Feed4Foodure aims to contribute to sustainable and healthy livestock farming in the Netherlands, simultaneously strengthening its competitive position on the global market. The Feed4Foodure program line "MVV5", aims to reduce the soybean meal content of South American origin, and thus reducing the amount of non-EU protein in the diet of pigs and poultry.

The current report describes the results of an experiment with male broilers in which the effects of low crude protein diets, with a partial replacement of soybean meal by free amino acids, on growth performance, slaughter yields, litter quality, footpad lesions, economical performance and the ecological footprint were evaluated. For the current study, scientists of Wageningen UR Livestock Research worked together with representatives from the consortium. The authors thank the industry partners of the project team for their worthwhile input.

Marinus van Krimpen, project leader. 


\section{Summary}

Providing diets to broilers with a reduced crude protein (CP) content that are supplemented with increased levels of free amino acids (AA) to cover their AA requirements might be helpful in reducing the use of soybean meal of South American origin, and thus in reducing the amount of non-EU protein in broiler diets. For maintaining performance levels of broilers that are fed low CP diets, the AA supply is essential. Broiler diets are usually at least optimised for minimum lysine, methionine + cysteine, threonine and tryptophan requirements. In low CP diets, the requirements for the AA valine, isoleucine, serine and glycine should be taken into account as well.

A study was conducted in which the effects of low CP diets, with a partial replacement of soybean meal by free $A A$, on technical performance, slaughter yields, litter quality, footpad lesions, economical performance and the ecological footprint were evaluated. In this study, dietary soybean meal content in the grower diets was reduced from $27.3 \%$ (control) to $17.3 \%$ (CP-3\%), while soybean meal content in the finisher diets was reduced from $25.0 \%$ (control) to $14.6 \%$ (CP-3\%). The study was carried out at the broiler trial facility of ForFarmers, Nijkerk, The Netherlands. This facility comprises 72 floor pens $\left(0.75 \mathrm{~m}^{2}\right)$, of which 68 were used for this study. All pens were bedded with white wood shavings and housed 13 male broilers. The lighting schedule was $23 \mathrm{~h} \mathrm{~d}^{-1}$ from 0 to $2 \mathrm{~d}, 18 \mathrm{~h} \mathrm{~d}^{-1}$ from 3 to $35 \mathrm{~d}$, and the temperature was gradually decreased from $34^{\circ} \mathrm{C}$ to $20^{\circ} \mathrm{C}$ at $34 \mathrm{~d}$ of age.

Broilers received a 3-phase diet programme: starter ( 0 to $11 d$ ), grower (11 to $28 \mathrm{~d}$ ) and finisher (28 to $35 \mathrm{~d}$ of age). All broilers received the same starter diet, and thereafter four feeding programmes with different levels of dietary CP (control, and three low protein diets with $1 \%(\mathrm{CP}-1 \%), 2 \%(\mathrm{CP}-2 \%)$ and $3 \%(\mathrm{CP}-3 \%$ ) less CP per period) were tested. The control diet programme had had a crude protein content in the grower and finisher phase of 208 and $198 \mathrm{~g} / \mathrm{kg}$, respectively. All diets were formulated to meet or exceed the requirements concerning faecal digestible AA, and to be iso-caloric within each feeding phase. Feed and water were provided for ad libitum intake during the entire experimental period.

Reducing dietary CP content up to 3\%, while maintaining dietary concentrations of essential AA resulted in similar growth performance or even better growth performance results as broilers fed the control diet program. The best overall performance was obtained with the $\mathrm{CP}-2 \%$ diet program. Over the entire experimental period $(0-35 d)$ none of the low protein diet programs affected body weight gain, feed intake or mortality. However, the crude protein efficiency improved with the decline of the crude protein content of the diet. Broilers fed the $\mathrm{CP}-1 \%$ diet program had numerically but not significantly a better feed conversion ratio compared to the control fed birds. Broilers fed the CP- $2 \%$ or $\mathrm{CP}-3 \%$ diet program had a statistically improved feed conversion ratio.

Broilers fed the low protein diet programs had a lower water intake, a better litter quality and less severe footpad lesions, thus a lower footpad score compared to broilers fed the control diet program.

Providing broilers diets with up to a $3 \%$ lower crude protein content while maintaining dietary concentrations of essential AA hardly influenced the slaughter yields. Only the breast meat yield, expressed as \% of the carcass, of broilers fed the diet with $3 \%$ lower CP content was lower, while the breast meat weight did not differ.

Lowering the crude protein content substantially reduced the inclusion of non-European protein (soybean meal, SBM) in the diets, but increased the calculated dietary carbon footprint as well the feed price. A $1 \%$ lower crude protein content reduced the amount of SBM with 2.5 percent, but the carbon footprint and feed price increased with 6 and 3 percent, respectively. A 3\% reduction of the crude protein content reduced the SBM content with 10.2, and increased the carbon footprint and feed price with respectively with 19 and 10 percent. Low crude protein diets had, despite the better growth performance results, a lower feed margin at farm level. Compared with the control CP group the feed margin per broiler placed of the $\mathrm{CP}-1 \%, \mathrm{CP}-2 \%$ and $\mathrm{CP}-3 \%$ was $2.6,2.4$ and 6.1 €cent lower, respectively. 


\section{Introduction}

The world population is growing and the demand for animal products is increasing (FAO, 2006). It is expected that the demand for poultry meat will grow rapidly worldwide, and thus also the demand for plant proteins, e.g. soybean meal, will increase. The accessibility of plant proteins for feed is expected to decline with an increasing demand for more highly digestible diet ingredients to be used for human consumption rather than for inclusion in animal diets. In Europe, the rate of self-sufficiency for soybean meal, however, is only $2 \%$ (FEFAC, 2015), indicating the extreme dependency for this important protein source on other areas, mainly South America. The European Parliament is concerned that such a massive dependency on imports makes the EU livestock sector extremely vulnerable to price volatility and trade distortions, causing feed price to rise, thereby increasing farmers' production costs and reducing the sectors' profitability (Euractiv, 2011). A major concern of NGO's is the deforestation of tropical rain forest, to fulfil the need of arable land for soybean cultivation (WNF, 2011; Van Gelder and Kuepper, 2012). As a consequence of conversion of natural ecosystems into agriculture, the rate of biodiversity loss (proportion of extinct species) increases, whereas the current status has already more than ten times exceeded the proposed boundary (Rockström et al., 2009). Moreover, large scale soybean cultivation may increase water and soil pollution, and drive small farmers and the native population out of business (WNF, 2011). It is, therefore, important to find alternatives for imported soybean meal.

A lower inclusion of soybean protein in broiler diets is one way to reduce the use of soybean in Europe. This can be done by partial replacing soy products by other protein commodities as: peas, rapeseed / rapeseed meal, sunflower meal, fish meal, corn gluten meal, and / or potato protein. Soybean meal has a balanced amino acids pattern that meets the requirements of most of the amino acids of poultry, and a complete replacement of soybean meal by the aforementioned protein-rich feed stuffs, with a less balanced pattern of amino acids, will result in an increase of the use of free amino acids. Partial replacement of soybean meal by free amino acids seems, in view of the economic aspects, is more obvious.

The provision of diets with a lower crude protein content was suggested to reduce the carbon footprint, because less of soybean meal in the feed needs to be transported and processed. Reducing the crude protein content of broiler diets, however, will increase the risk of reduced growth performance, when (semi-) essential amino acids become limiting. In order to successfully reduce crude protein in broiler feeds, thus to maintain growth performance results, it is essential to keep the supply and the balance of most limiting amino acids in line with the broiler requirement through an adequate dietary supplementation of free amino acids. Findings in literature show that, as long as contents of lysine and the ratio of the other essential amino acids to lysine are maintained, low protein diets allow to achieve maximum level of performance (Waldroup et al., 1976; Kerr and Kidd, 1999; Aletor et al., 2000; Dean et al., 2006; Namroud et al., 2008). However, in low protein diets also glycine and serine, that currently are considered as non-essential amino acids, (Dean et al., 2006) can become growth limiting, either because there are not enough metabolic precursors for the respective amino acids available, or because endogenous metabolization processes are too slow (Aftab et al., 2006; Berres et al., 2010). This could well be the reason why several researchers found decreased performance results with low protein diets supplemented with amino acids, without maintaining the glycine + serine to lysine ratio (e.g. Ferguson et al., 1998a,b; Bregendahl et al, 2002).

When the crude protein content is reduced, glycine and serine levels decrease as well (Dean et al., 2006). Therefore, it is possible that marginal levels of dietary glycine and serine are the reason for the decrease in performance of broilers when feeding low protein diets, even if they are supplemented with essential amino acids. Several studies showed that glycine supplementation avoid the adverse effects on broiler performance when low protein diets were provided (Ospina-Rojas et al., 2012; Ospina-Rojas et al., 2013; Ospina Rojas et al., 2014). In a study of Veldkamp et al. (2016, in press) with broiler chickens from 8-35 days of age, reduced growth performance results were found of 
broilers fed low protein diets, despite essential amino acids (lysine, methionine, tryptophan, threonine, arginine and isoleucine) were supplemented to $10 \%$ above CVB (2012) requirements. The authors suggested that the lack of glycine and serine might explain the reduced growth performance results in low protein diets. Because of the importance of glycine in low-protein diets, it is considered as the fourth limiting amino acid after lysine, methionine and threonine (Waguespack et al., 2009). Also according to Ospina-Rojas (2013), glycine is a limiting amino acid in low protein diets, especially in the starter phase but also afterwards. Based on the obtained results in the study of Veldkamp et al.

(2016) and in the literature, it is decided in the present study to add free glycine to low protein diets, aiming to maintain the production results of broilers.

A large part of the dietary nitrogen intake is not retained by the animal, but excreted into the environment. Lowering the crude protein content of the diet could therefore be a tool to reduce the nitrogen excretion and ammonia emission from broiler houses (Elwinger and Svensson, 1996; Van Harn and Van Middelkoop, 1996; Kidd et al., 1996; Ferguson et al., 1998a; Nahm, 2002; Khajali and Moghaddam, 2006; Namroud, et al., 2008; Hernandez et al., 2013). Moreover, low crude protein levels in broiler diets reduce the risk of digestion problems and necrotic enteritis. A reduced crude protein would also lead to less water intake, because there is a reduced need to get rid of the protein surplus (Bailey, 1999; Elwinger and Svensson, 1996). A lower water intake reduces the risk of wet litter, and thus risk of an impaired welfare since wet litter is the main reason for skin dermatitis such as footpad lesions, hock burns and breast blisters. Wet litter could also lead to more rejections at the slaughter house (Shephard and Fairchild, 2010).

Besides the fact that providing low protein diets to broilers reduces the use of soybean meal, it could also by an efficient tool to improve intestinal health (less digestive disorders and improved health status), animal welfare (less dermatitis) and to reduce environmental emissions (less $\mathrm{N}$-excretion and ammonia emission) (Qaisrani et al., 2015; Apajalahti and Vienola, 2016).

An experiment was performed with male broilers in which the effects of feeding low crude protein diets, with an $1 \%, 2 \%$ or $3 \%$ reduced crude protein content but supplemented with free amino acids (including glycine), thereby partial replacing soybean meal, on growth performance, slaughter yields, litter quality, litter composition and animal welfare were studied. Also the consequences of adjusting the dietary protein content of the diets on the feed costs and carbon footprint of the diets were calculated. 


\section{Materials and Methods}

\subsection{Study objective}

The objective of this study was to evaluate the effects of low crude protein diets, with a partial replacement of soybean meal by free amino acids, on growth performance, slaughter yields, litter quality, footpad lesions, economical performance and the ecological footprint.

Low crude protein diets were supplemented with free amino acids and provided from 11 - 35 days of age.

\subsection{Start date and end date of the experiment}

Start date: 7 January 2016

End date: 11 February 2016

\subsection{Experimental animals}

A total of 936 day-old male Ross 308 broiler chicks were used and allocated to 72 floor pens bedded with wood shavings (13 animals/pen). The broilers were sexed at the hatchery. The experiment started at 1 day of age and the experiment was completed at 35 days of age. All broilers were from the same parent stock (VB 3358) and age of the parent stock was 36 weeks.

\subsection{Experimental design}

The experiment was carried out at the experimental broiler house of feed producer ForFarmers. This natural ventilated house locates 72 floor pens of $0.75 \mathrm{~m}^{2}$, of which 68 were used for this study. A completely randomized block design, consisting of four treatments and seventeen blocks, was used in this experiment. A block consisted of 4 consecutive pens (Appendix 1). Each treatment was replicated seventeen times and the experimental unit was a pen with 13 male broilers (Table 2.1). Treatments were randomly allotted among pens. Randomization was conducted within blocks to create a balanced distribution of treatments within blocks, and over the experimental room taking into account front and backside of the facility. The treatments and a description of the treatments are presented in Table 2.2.

Table 2.1 Experimental design in summary.

\begin{tabular}{lr} 
Item & Number \\
\hline Treatments & 4 \\
\hline Broilers per pen & 13 \\
\hline Broilers per treatment & 221 \\
\hline Total number of broilers & 884 \\
\hline Number of blocks & 17 \\
\hline Replicates (pens) per treatment & 17 \\
\hline Total number of pens & 68 \\
\hline
\end{tabular}


Table 2.2 Experimental treatments.

\begin{tabular}{ll} 
Treatment & Description \\
\hline 1 & Control, standard crude protein $(\mathrm{CP})$ \\
\hline 2 & Control $-1 \% \mathrm{CP}$; diet with a $1 \%$ lower $\mathrm{CP}$, but similar digestible amino acids (dAA) ${ }^{1}$ to control \\
\hline 3 & Control $-2 \% \mathrm{CP}$; diet with a $2 \%$ lower $\mathrm{CP}$, but similar dAA ${ }^{1}$ to control \\
\hline 4 & Control $-3 \% \mathrm{CP}$; diet with a $3 \%$ lower $\mathrm{CP}$, but similar dAA ${ }^{1}$ to control \\
\hline
\end{tabular}

1 Lysine, methionine, threonine, valine, arginine, isoleucine, glycine and tryptophan.

\section{$2.5 \quad$ Experimental diets}

The experimental diets were formulated by ForFarmers and produced by Research Diet Services, Wijk bij Duurstede, The Netherlands. A three-phase diet program was provided. Starter, grower and finisher diets were provided from $0-11,11-28$ and 28 - 35 days of age, respectively. During the starter phase all animals receive the same diet with crude protein content of $216 \mathrm{~g} / \mathrm{kg}$. Thereafter, four diet programmes with different crude protein levels (control, and three low protein programmes with $1 \%(\mathrm{CP}-1 \%), 2 \%(\mathrm{CP}-2 \%)$ and $3 \%(\mathrm{CP}-3 \%)$ less $\mathrm{CP}$ per period) but similar essential digestible amino acids levels were provided. The control diet programme had had a crude protein content in the grower and finisher phase of 208 and $198 \mathrm{~g} / \mathrm{kg}$, respectively. The diets were formulated to meet or exceed the requirements concerning faecal digestible AA (lysine, methionine, threonine, tryptophan, isoleucine, valine, arginine and glycine), and to be iso-caloric within each period. All diets for each period were prepared with the same batch of ingredients. Dietary soybean meal content in the grower diets reduced from $27.3 \%$ (control) to $17.3 \%$ (CP-3\%), while soybean meal content in the finisher diets reduced from $25.0 \%$ (control) to $14.6 \%$ ( $\mathrm{CP}-3 \%$ ). The ingredient and nutrient composition (incl. $\mathrm{AA}$ ratios relative to lysine) were established in consultation with the F4F project partners (Table 2.3).

Table 2.3 Calculated contents of energy $(\mathrm{kcal} / \mathrm{kg})$, crude protein and essential amino acids $(\mathrm{g} / \mathrm{kg}) \mathrm{in}$ the experimental diets.

\begin{tabular}{|c|c|c|c|c|c|c|c|c|c|c|}
\hline & & \multirow{2}{*}{$\begin{array}{l}\text { Starter } \\
\text { Contr. }\end{array}$} & \multicolumn{4}{|c|}{ Grower diets } & \multicolumn{4}{|c|}{ Finisher diets } \\
\hline & & & Contr. & $-1 \%$ & $-2 \%$ & $-3 \%$ & Contr. & $-1 \%$ & $-2 \%$ & $-3 \%$ \\
\hline AMEn broiler & $\mathrm{kcal} / \mathrm{kg}$ & 2900 & 3000 & 3000 & 3000 & 3000 & 3025 & 3025 & 3025 & 3025 \\
\hline Crude protein & $\mathrm{g} / \mathrm{kg}$ & 216 & 208 & 198 & 188 & 178 & 198 & 188 & 178 & 168 \\
\hline Dig. Iysine & $\mathrm{g} / \mathrm{kg}$ & 11.5 & 10.5 & 10.5 & 10.5 & 10.5 & 9.9 & 9.9 & 9.9 & 9.9 \\
\hline Dig. methionine & $\mathrm{g} / \mathrm{kg}$ & 5.6 & 5.0 & 5.1 & 5.3 & 5.5 & 4.7 & 4.9 & 5.1 & 5.2 \\
\hline Dig. meth+cys & $\mathrm{g} / \mathrm{kg}$ & 8.5 & 7.9 & 7.9 & 7.9 & 7.9 & 7.5 & 7.5 & 7.5 & 7.5 \\
\hline Dig. threonine & $\mathrm{g} / \mathrm{kg}$ & 7.5 & 6.8 & 6.8 & 6.8 & 6.8 & 6.4 & 6.4 & 6.4 & 6.4 \\
\hline Dig. tryptophan & $\mathrm{g} / \mathrm{kg}$ & 2.37 & 2.30 & 2.30 & 2.30 & 2.30 & 2.17 & 2.17 & 2.17 & 2.17 \\
\hline Dig. isoleucine & $\mathrm{g} / \mathrm{kg}$ & 7.8 & 7.4 & 7.4 & 7.4 & 7.4 & 7.0 & 7.0 & 7.0 & 7.0 \\
\hline Dig. valine & $\mathrm{g} / \mathrm{kg}$ & 9.2 & 8.4 & 8.4 & 8.4 & 8.4 & 7.9 & 7.9 & 7.9 & 7.9 \\
\hline Dig. arginine & $\mathrm{g} / \mathrm{kg}$ & 12.5 & 12.0 & 12.0 & 12.0 & 12.0 & 11.3 & 11.3 & 11.3 & 11.3 \\
\hline Dig. glycine + serine & $\mathrm{g} / \mathrm{kg}$ & 16.3 & 15.7 & 15.7 & 15.7 & 15.7 & 14.9 & 14.9 & 14.9 & 14.9 \\
\hline
\end{tabular}

The ingredient composition and the complete calculated nutrient contents of all diets are presented in Appendix 2. In Appendix 3 the AA ratio to lysine is provided per feeding phase.

All diets were pelleted (starter diets as $2.5 \mathrm{~mm}$ diameter pellets, grower and finisher diets both as 3.2 $\mathrm{mm}$ diameter pellets) using a limited amount of steam (pellet temperature $<70^{\circ} \mathrm{C}$ ).

\subsection{Animal and housing conditions}

A total number of 936 day-old male broilers Ross 308 were obtained from a commercial hatchery (Probroed \& Sloot, Groenlo, The Netherlands), and equally distributed to 72 floor pens (floor space: $0.75 \mathrm{~m}^{2}$ ) bedded with wood shavings $\left(2 \mathrm{~kg} / \mathrm{m}^{2}\right)$. The floor pens were located in the natural ventilated poultry house of J.W. van Essen, Nijkerk, The Netherlands. Sixty eight of these 72 pens were used for this trial. In the remaining four pens, reserve animals were housed, which were used to standardize the number of animals in the experimental pens in case of mortality during the starter phase $(0-$ 
11d). These reserve animals were fed the same starter diet. Therefore, the number of animals per pen was similar for all pens at day 11 (= start providing experimental diets). Per pen 13 broilers were placed. The housing, management, feeding and husbandry conditions are standard and representative for a modern commercial broiler operation in Europe.

Water and feed were provided ad libitum during the entire experimental period ( $0-35$ days of age). Feed was supplied via feeding bins (feeding space/pen $0.75 \mathrm{~m}$ ). These bins were constructed in a way that feed spillage was limited. Water was supplied by one drinking cup (Impex) per pen (Figure 2.1). One day prior to placement of the broilers, the room was pre-heated to $30^{\circ} \mathrm{C}$. The temperature at placement of the broilers was $34^{\circ} \mathrm{C}$ and this temperature was decreased gradually to $20^{\circ} \mathrm{C}$ at 34 days of age (Table 2.4). During the first two days light was nearly continuous on (23L:1D), from $3-35$ days of age a day/night schedule of $18 \mathrm{~h}$ light and $6 \mathrm{~h}$ dark (18L:6D) was given per $24 \mathrm{~h}$. Light intensity was 20 lux during the entire experimental period.

Visual observation of the birds was done twice per day to check animal health. All broilers were vaccinated against New Castle Disease (ND Clone 30, spray vaccination) at 15 days of age at the experimental facility.
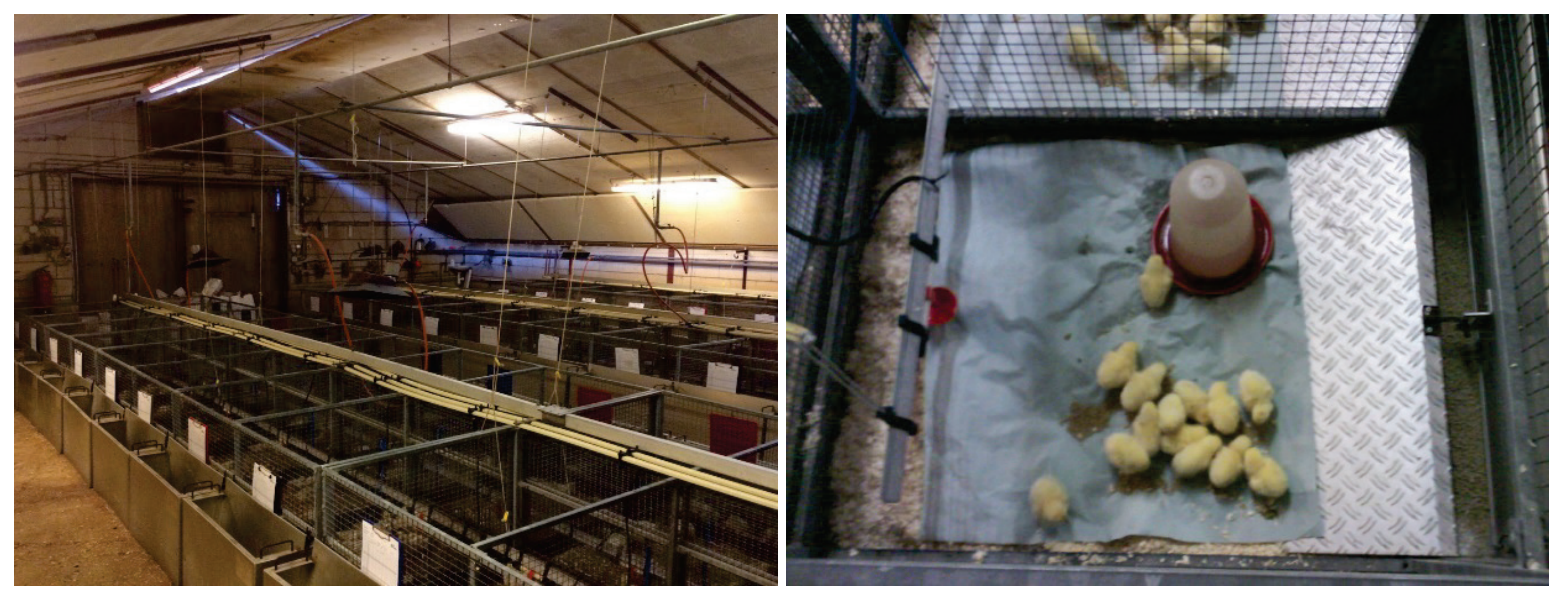

Figure 2.1 Left: experimental room; Right: experimental pen with day-old broilers.

Table 2.4 Temperature schedule.

\begin{tabular}{ll} 
Age & Set temperature $\left({ }^{\circ} \mathrm{C}\right)$ \\
\hline 0 & 34 \\
\hline 2 & 33 \\
\hline 4 & 31 \\
\hline 6 & 30 \\
\hline 8 & 29 \\
\hline 10 & 28 \\
\hline 14 & 27 \\
\hline 18 & 25 \\
\hline 21 & 22 \\
\hline 28 & 20 \\
\hline 34 & 20 \\
\hline $34-$ slaughter & 32 \\
\hline
\end{tabular}




\subsection{Observations and measurements}

\section{a Diets}

After pelleting, and just before bagging, each diet was sampled (i.e. at intervals of $20 \mathrm{~kg} \mathrm{diet).}$ These samples were pooled to form a composite, representative sample of each diet. All diets ( 1 starter, 4 grower and 4 finisher diets) were analysed on contents of dry matter, crude protein, crude fat, crude fibre, ash, starch and amino acids. All proximate analyses were performed at the laboratory of ForFarmers, Lochem, The Netherlands. The amino acid analyses were performed at Evonik Nutrition \& Care GmbH, Hanau-Wolfgang, Germany.

\section{a Performance}

Body weight (BW) of birds per pen was determined at 0, 11, 28 and 35 days of age. Feed intake (FI) per pen was determined at 11,28 and 35 days of age (provided feed minus remaining feed at 11,28 and 35 days of age). Body weight gain (BWG), average daily gain (ADG), feed conversion ratio (FCR), feed intake (FI), average daily feed intake (ADFI) were calculated on a pen basis from these data for the following periods: $0-11 d, 11-28 d, 28-35 d, 11-35 d$ and $0-35 d$. BWG = BW end period - BW start period; $A D G=B W G /$ length period; FCR = (Total FI / (Total BW end period - total BW start period + total BW of dead or culled birds)); FI = FCR $\times$ BWG; ADFI = FI / length period. The crude protein conversion (CPC) was calculated over the above mentioned periods. CPC = FI (kg) x CP content diet $(\mathrm{g} / \mathrm{kg}) /$ BWG $(\mathrm{g})$. Culling, mortality and health were recorded daily (including probable causes of any culling, illness or deaths). EPEF (European Production Efficiency Factor) was calculated per pen at 35 days. EPEF was calculated as (mean daily body weight gain (g)/FCR*10) x (100 - \% mortality).

Water intake was measured, but not per pen but per treatment per two rows. As the feed intake per pen is known, the cumulative feed intake per treatment in these two rows could be calculated. By dividing cumulative water intake by cumulative feed intake, the average water/feed ratio per treatment in these two rows was calculated. By multiplying the average water/feed ratio per two rows and the feed intake per pen the water intake per pen could be estimated.

Twice daily, in the morning and the afternoon, animals and housing facilities were inspected by the farmer, thereby checking the general health status, continuous supply of feed and water as well as lighting, temperature and ventilation, and recognizing unexpected events. All incidences were recorded.

If an animal was in poor condition, health status was observed more frequently. Birds suffering pain or distress were selected, culled and the cause of the death or distress was recorded. In all cases of mortality, birds were weighed and date of death was recorded.

- Slaughter yields

Slaughter yields of 10 randomly selected birds per pen were determined at 35 days of age. Selected birds were removed, individually marked and weighed and transported to a commercial slaughter house. At the slaughter house the broilers were cut up by hand by trained personnel to determine carcass, wing, leg (thigh + drums), back, breast meat and skin weight and yield. All yields were expressed as percentage of carcass weight, except carcass yield which is expressed as percentage of the live body weight. All measurements were performed by Plukon, Wezep, The Netherlands.

L Litter quality assessment Litter quality was visually scored at 35 days of age by an experienced assessor, who scored the friability and wetness of the litter in each pen on a 1 to 10 point scale. The scores and the description of each score are presented in Table 2.5. 
Table 2.5 Scores for friability and wetness of the litter and a description of each score.

\begin{tabular}{lll} 
Score & Friability description & Wetness description \\
\hline 1 & Complete caked litter & Wet litter, total area by pressure on the litter water is appearing \\
\hline 3 & $80-90 \%$ of the area is caked & Wet litter, beneath drinking line by pressure on the litter water is appearing \\
\hline 4 & $70-80 \%$ of the area is caked & Wet litter, beneath drinking line by pressure on the litter no water is \\
& appearing
\end{tabular}

\section{a Litter composition}

At the end of the study representative samples of the litter were taken from pens $13-60$. These samples were analysed on: dry matter, total $\mathrm{N}$, ammonium $\mathrm{N}$ and $\mathrm{pH}$. These analyses were done by the service lab of Wageningen Livestock Research, Wageningen, The Netherlands.

\section{Footpad lesions}

Occurrence of footpad lesions and their severity (scale $0,1,2$ ) was determined at 34 days of age by an experienced assessor. All broilers per pen were used for these assessments. Footpad dermatitis was scored per broiler for both feet according to the so-called 'Swedish' classification, i.e. score 0: no lesions or very small discolouration; score 1: discoloration but no deep lesion; score 2: deep lesion with ulcers or scabs, bumble foot (Berg, 1998). An overview of scores for footpad lesions is presented in Appendix 4.

The severity of footpad lesions was expressed as footpad score (FPS) per pen. This score is calculated as follows: $100 \% *((0.5 *$ the total number of birds with score 1$)+(2 *$ the total number of birds with score 2)) / the total number of scored birds. The flock FPS ranges from 0 (all birds having no lesions) to 200 (all birds having score 2).

Economic calculations

An economic calculation was performed based on obtained growth performance results and slaughter yield results obtained in the current experiment. Prices were based on KWIN-V 20162017 and Bedrijfswijzer Pluimvee (described by Vellinga et al. (2013) and Vermeij and Kanis (2005)).

\subsection{Statistical analysis}

Raw data were analysed for statistical outliers. An outlier was defined as an observation which is deviating more than 2.5 standard deviations from the mean. If the deviation of an observation was more than 2.5 times the standard deviation from the mean and there was a plausible reason for this deviation, the observation was excluded from the dataset. The experimental data were analysed using GenStat statistical software (GenStat ${ }^{\mathrm{TM}}$ Release 18.1) on Windows 7.

The P-value of the treatment effect and the LSD (least significant difference $(P=0.05)$ ) were provided per response parameter. Treatment effects with a P-value $<0.05$ were considered to be statistically significant. 
Response parameters were analysed using ANOVA (analysis of variance) according the following model:

$Y_{i j}=\mu+$ Treatment $_{i}+$ Error $_{i j}$

Where:

$\begin{array}{ll}\mathrm{Y} & \text { Response parameter } \\ \mu & \text { General mean } \\ \text { Treatment } & \text { Effect of diet }(\mathrm{i}=1 \ldots 4) \\ \text { Error } & \text { Error term }\end{array}$

Row and pen within row were included in the model as random terms. 


\section{Results}

\subsection{General}

Average body weight of the chickens at arrival was 37.6 grams. Overall mortality during the experiment was $5.1 \%$, which is slightly higher than the average Dutch standard (3.5\%, KWIN 2016/2017). For this experiment, however, only male broilers were used and it is well known that the mortality of male broilers is higher than of female broilers.

Average body weight at 35 days was 153 gram higher (2436 vs. 2283 grams), and average feed conversion ratio over the entire experimental period ( 0 - 35 days) was slightly lower (1.526 vs. 1.537 $\mathrm{g} / \mathrm{g}$ ) compared to the Ross 308 male broiler performance objectives (Aviagen, 2014) (Figure 3.1).
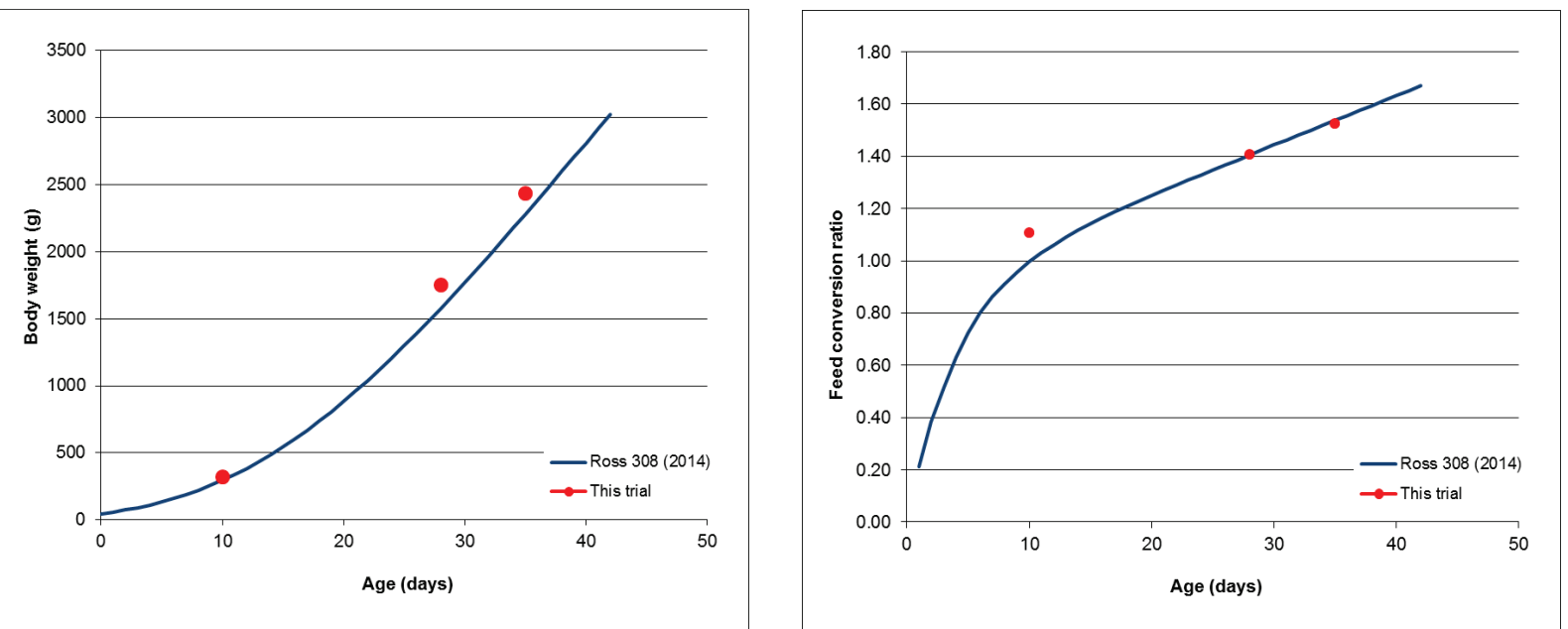

Figure 3.1 Average body weight (left) and feed conversion ratio (right) achieved in this experiment compared with the Ross 308 broiler male performance objectives (Aviagen, 2014)

\subsection{Diet analyses}

In Table 3.1 the calculated and analysed nutrient composition of the starter, grower and finisher diets are given.

Table 3.1 The calculated and analysed nutrient composition $(\mathrm{g} / \mathrm{kg})$ of the starter diet, grower and finisher diets

\begin{tabular}{|c|c|c|c|c|c|c|c|c|c|c|}
\hline \multirow[t]{2}{*}{ Nutrient } & & \multirow{2}{*}{$\begin{array}{l}\text { Starter } \\
\text { diet }\end{array}$} & \multicolumn{4}{|c|}{ Grower diets } & \multicolumn{4}{|c|}{ Finisher diets } \\
\hline & & & $\begin{array}{c}\text { Control } \\
\mathrm{CP}\end{array}$ & $\begin{array}{l}\text { CP- } \\
1 \%\end{array}$ & $\begin{array}{l}\text { CP- } \\
2 \%\end{array}$ & $\begin{array}{l}\text { CP- } \\
3 \%\end{array}$ & $\begin{array}{c}\text { Control } \\
\mathrm{CP}\end{array}$ & $\begin{array}{l}\text { CP- } \\
1 \%\end{array}$ & $\begin{array}{l}C P- \\
2 \%\end{array}$ & $\begin{array}{l}\mathrm{CP}- \\
3 \%\end{array}$ \\
\hline Crude protein (calc) & $\mathrm{g} / \mathrm{kg}$ & 216 & 208 & 198 & 188 & 178 & 198 & 188 & 178 & 168 \\
\hline Crude protein.(ana) & $\mathrm{g} / \mathrm{kg}$ & 207 & 200 & 194 & 186 & 178 & 191 & 184 & 176 & 168 \\
\hline Crude fat (calc) & $\mathrm{g} / \mathrm{kg}$ & 67 & 83 & 76 & 70 & 64 & 79 & 71 & 66 & 60 \\
\hline Crude fat (ana) & $\mathrm{g} / \mathrm{kg}$ & 68 & 81 & 76 & 70 & 66 & 75 & 71 & 66 & 61 \\
\hline Crude fibre (calc) & $\mathrm{g} / \mathrm{kg}$ & 35 & 37 & 36 & 35 & 34 & 35 & 35 & 34 & 34 \\
\hline Crude fibre (ana) & $\mathrm{g} / \mathrm{kg}$ & 34 & 37 & 37 & 35 & 36 & 37 & 38 & 38 & 34 \\
\hline Crude ash (calc) & $\mathrm{g} / \mathrm{kg}$ & 54 & 48 & 47 & 46 & 44 & 43 & 42 & 40 & 39 \\
\hline Crude ash (ana) & $\mathrm{g} / \mathrm{kg}$ & 51 & 47 & 46 & 45 & 42 & 42 & 40 & 39 & 36 \\
\hline Starch Brunt (calc) & $\mathrm{g} / \mathrm{kg}$ & 353 & 351 & 373 & 397 & 421 & 376 & 399 & 421 & 445 \\
\hline Starch Brunt (ana) & $\mathrm{g} / \mathrm{kg}$ & 347 & 350 & 364 & 385 & 404 & 359 & 379 & 407 & 432 \\
\hline
\end{tabular}


From this table, it can be concluded that the crude protein level of the starter diet was relatively $4.2 \%$ lower than calculated. Crude protein level of the control grower and finisher diets were respectively 3.8 and $3.5 \%$ lower than calculated. The differences between analysed and calculated crude protein decreased with decreasing crude protein. Although the analysed differences in crude protein content were lower than calculated (the absolute difference in crude protein content between control and CP$3 \%$ was $2.2 \%$ and $2.3 \%$ for grower and finisher diet, respectively, instead of $3 \%$ ) the differences in crude protein content between treatments were still in line with the experimental set-up. The analysed starch content of most diets, except grower control, was lower than calculated. On average the difference in calculated and analysed starch content was $3 \%$. Analysed crude fat, crude fibre and crude ash content met the calculated values.

Table 3.2 Calculated and analysed amino acids contents of the grower and finisher diets

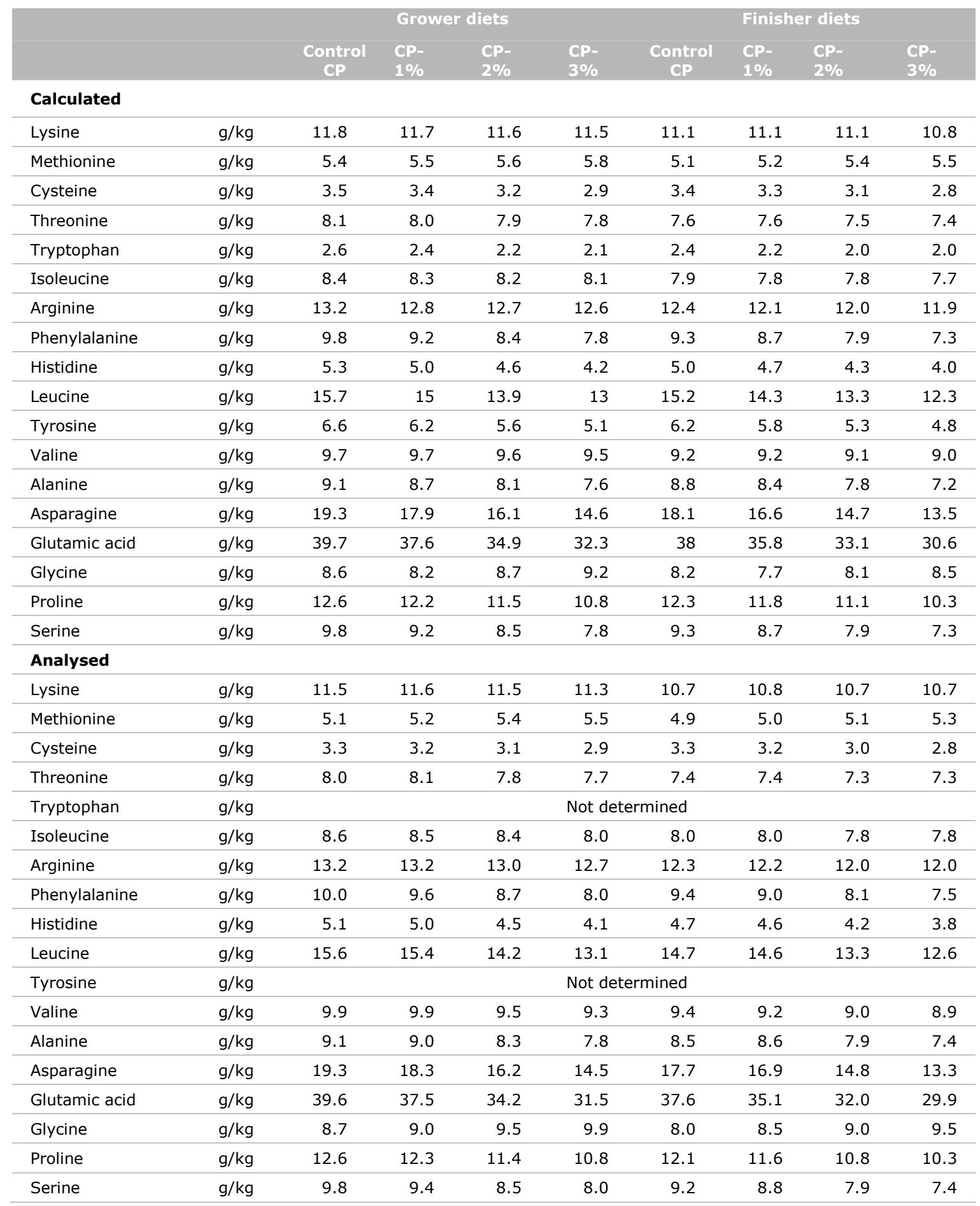


In Table 3.2 the calculated and analysed amino acids (AA) contents of the grower and finisher diets are given. Appendix 5 presented the relative differences (in \%) between calculated and analysed amino acids contents of the grower and finisher diets.

It can be concluded that in general the analysed AA contents met the calculated contents. It is noteworthy that when free glycine was added, a strong increase of the analysed glycine content is analysed. This increase of the glycine content in the analysis must be related to glycine present in protein in the ingredients, because the amount of supplemented free glycine was close to the formulated inclusion levels. The former excludes a dosing error of glycine.

\subsection{Growth performance results}

This paragraph describes the growth performance results obtained in the grower phase (11 -28 days), finisher phase (28 - 35 days), grower and finisher phase (11 - 35 days) and the overall experimental period ( 0 - 35 days). In Appendix 6 the obtained growth performance results from 0 - 11 days (starter phase) of age are given.

\subsubsection{Grower phase}

In Table 3.3, the growth performance results from 11 - 28 days of age are given. From these results it can be concluded that providing low protein diets supplemented with free AA including glycine had no negative effect on the performance results compared to the control, a grower diet with $208 \mathrm{~g} / \mathrm{kg}$ dietary protein.

Body weight (BW), body weight gain (BWG), mortality, feed conversion ratio (FCR) and feed intake were not affected by any of the low protein treatments. However, the crude protein conversion decreased with the decline of the crude protein content of the diets, which means that broilers fed the diet with the lowest crude protein had the highest protein efficiency. The water intake and water/feed ratio decreased with the decrease of the crude protein content of the feed.

Table 3.3 Performance results per treatment from 11 - 28 days of age (grower phase)

\begin{tabular}{|c|c|c|c|c|c|c|}
\hline & Control CP & $\mathrm{CP}-1 \%$ & $\mathrm{CP}-2 \%$ & $\mathrm{CP}-3 \%$ & F-prob & LSD \\
\hline Body weight $11 \mathrm{~d}(\mathrm{~g})$ & 324 & 323 & 323 & 321 & 0.656 & 4.3 \\
\hline Body weight $28 \mathrm{~d}(\mathrm{~g})$ & 1752 & 1751 & 1752 & 1739 & 0.759 & 29.1 \\
\hline Body weight gain $(\mathrm{g})$ & 1428 & 1428 & 1429 & 1417 & 0.811 & 27.7 \\
\hline Body weight gain $(\mathrm{g} / \mathrm{d})$ & 84.0 & 84.0 & 84.1 & 83.4 & 0.811 & 1.63 \\
\hline Mortality (\%) & 3.2 & 3.6 & 2.3 & 3.6 & 0.834 & 3.39 \\
\hline Feed conversion ratio $(\mathrm{g} / \mathrm{g})$ & 1.456 & 1.468 & 1.443 & 1.458 & 0.553 & 0.0340 \\
\hline Crude protein conversion $(\mathrm{g} / \mathrm{g})$ & $0.3029^{a}$ & $0.2906^{b}$ & $0.2713^{c}$ & $0.2595^{d}$ & $<.001$ & 0.0064 \\
\hline Feed intake $(\mathrm{g} / \mathrm{d})$ & 122.3 & 123.2 & 121.3 & 121.5 & 0.566 & 2.92 \\
\hline Water intake $(\mathrm{ml} / \mathrm{d})$ & $227.2^{a}$ & $217.5^{b}$ & $206.4^{c}$ & $199.4^{d}$ & $<.001$ & 4.98 \\
\hline Water/Feed ratio $(\mathrm{ml} / \mathrm{g})$ & 1.86 & 1.77 & 1.70 & 1.64 & & \\
\hline
\end{tabular}

$a, b, c, d$ Values without a common superscript per row differ significantly $(P<0.05)$.

\subsubsection{Finisher phase}

As in the grower phase, during the finisher phase (28 - 35 days), no adverse effects of lowering the crude protein content of the diet were found on BW, BWG, mortality and FI (Table 3.4). Broilers fed the CP-3\% diet had a better (lower) FCR compared to broilers fed the control diet or the CP-1\% diet. Broilers fed the CP- $2 \%$ diet had also a better FCR than the control fed broilers, but the FCR did not differ from the broilers who received $\mathrm{CP}-1 \%$ or $\mathrm{CP}-3 \%$ diets. The FCR of the broilers fed the $\mathrm{CP}-1 \%$ diet did not differ from the control fed birds. As in the grower phase the crude protein conversion, water intake and water/feed ratio linearly decreased with the decrease of the crude protein of the diet. Unlike the grower phase, the water intake of the broilers fed the CP-2\% diet did not differ from those who received $\mathrm{CP}-3 \%$ diet. 
Table 3.4 Performance results per treatment from 28 - 35 days of age (finisher phase)

\begin{tabular}{|c|c|c|c|c|c|c|}
\hline & Control CP & CP-1\% & CP-2\% & CP-3\% & F-Prob & LSD \\
\hline Body weight gain (g) & 666 & 685 & 697 & 708 & 0.143 & 37.0 \\
\hline Body weight gain $(g / d)$ & 95.2 & 97.9 & 99.6 & 101.1 & 0.143 & 5.29 \\
\hline Mortality (\%) & 2.6 & 1.5 & 0.5 & 1.0 & 0.458 & 2.69 \\
\hline Feed intake $(\mathrm{g} / \mathrm{d})$ & 184.2 & 183.8 & 179.0 & 179.1 & 0.175 & 6.25 \\
\hline Water intake (ml/d) & $341.2^{\mathrm{a}}$ & $316.3^{b}$ & $296.9^{c}$ & $294.1^{c}$ & $<.001$ & 10.85 \\
\hline Water/Feed ratio $(\mathrm{ml} / \mathrm{g})$ & 1.85 & 1.72 & 1.66 & 1.64 & & \\
\hline
\end{tabular}

$a, b, c, d$ Values without a common superscript per row differ significantly $(P<0.05)$.

\subsubsection{Grower and finisher phase}

In Table 3.5 the performance results from 11 - 35 days of age were given. In this period the broilers received the experimental grower $(11-28 d)$ and finisher diets $(28-35 d)$.

From 11 - 35 days of age dietary treatments did not alter BWG or FI. Broilers fed the control diet had the poorest FCR and broilers fed the CP- $2 \%$ diet the best. FCR of broilers fed the CP-1\% diet did not differ from the FCR of birds fed the control or the CP-3\% diets. Broilers fed CP- $2 \%$ or CP-3\% diets had improved FCR compared with the birds fed the control diets. Broilers fed the CP-3\% diets had the best crude protein conversion, followed by broilers fed the $\mathrm{CP}-2 \%, \mathrm{CP}-1 \%$ and control diets, respectively. The water intake decreased with the decrease of the crude protein content of the diet. Broilers fed the control diets had a higher water intake than birds who received $\mathrm{CP}-1 \%$ diet. Whereas broilers fed the $\mathrm{CP}-1 \%$ had a higher water intake than birds fed $\mathrm{CP}-2 \%$, which had a similar water intake as birds fed the $\mathrm{CP}-3 \%$ diet program. Dietary treatment did not influence the incidence of mortality.

Table 3.5 Performance results per treatment from 11-35 days (grower and finisher phase)

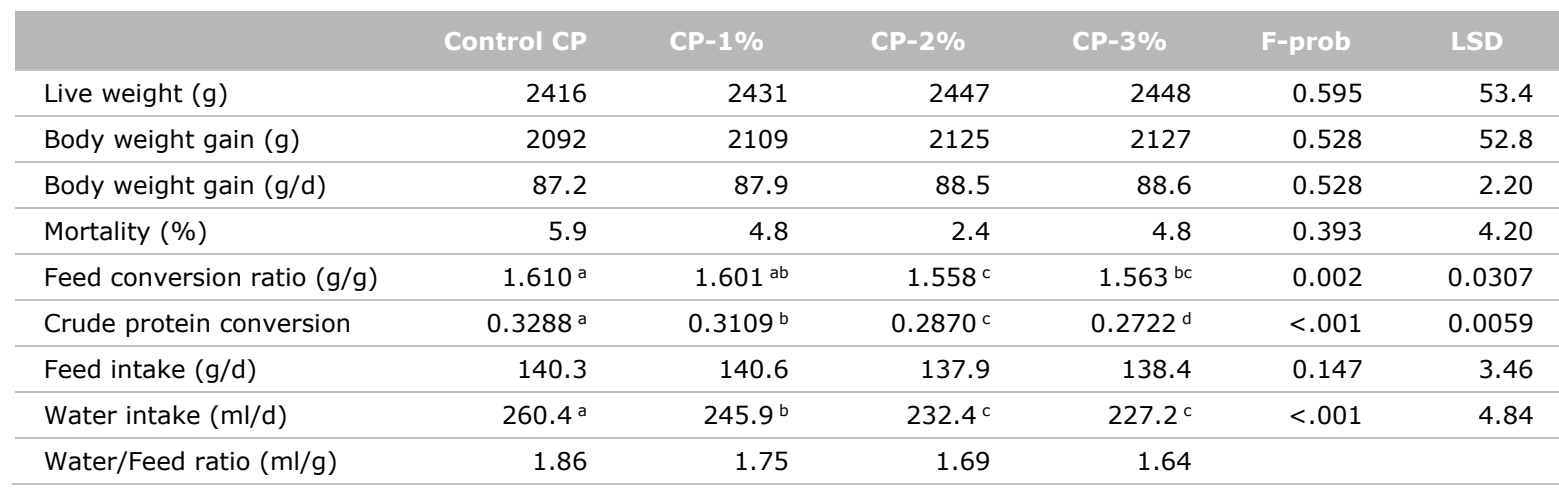

$a, b, c, d$ Values without a common superscript per row differ significantly $(P<0.05)$.

\subsubsection{Entire experimental period}

In Table 3.6 the growth performance results over the entire experimental period ( $0-35 d)$ are given.

From 0 - 35 days of age dietary treatments did not alter BW at 35d, BWG, mortality or FI. However FCR, crude protein conversion, and water intake were affected by dietary treatment. As from 11 $35 d$, broilers fed CP-2\% or CP-3\% diets had an improved FCR compared with the birds fed the control diet program, which had the poorest FCR. FCR of broilers fed the CP-1\% diet did not differ from broilers fed the control or the CP-3\% diet program, but the FCR was poorer than broilers fed CP- $2 \%$ diet program. 
Table 3.6 Performance results per treatment from 0 - 35 days of age (= complete experimental period)

\begin{tabular}{|c|c|c|c|c|c|c|}
\hline & Control CP & $\mathrm{CP}-1 \%$ & CP- $2 \%$ & $\mathrm{CP}-3 \%$ & F-prob & LSD \\
\hline Live weight (g) & 2416 & 2431 & 2447 & 2448 & 0.595 & 53.4 \\
\hline Body weight gain $(\mathrm{g} / \mathrm{d})$ & 68.0 & 68.4 & 68.8 & 68.9 & 0.595 & 1.53 \\
\hline Mortality (\%) & 6.0 & 5.8 & 2.5 & 6.3 & 0.324 & 4.72 \\
\hline Feed conversion ratio (field) $(\mathrm{g} / \mathrm{g})$ & 1.549 a & $1.542 \mathrm{ab}$ & $1.505^{c}$ & $1.510^{\mathrm{bc}}$ & 0.002 & 0.0265 \\
\hline Crude protein conversion & $0.3178^{a}$ & $0.3023^{b}$ & $0.2814^{c}$ & $0.2685^{d}$ & $<.001$ & 0.0051 \\
\hline Feed intake $(\mathrm{g} / \mathrm{d})$ & 105.2 & 105.4 & 103.6 & 103.9 & 0.147 & 1.93 \\
\hline Water intake $(\mathrm{ml} / \mathrm{d})$ & $196.6^{a}$ & $186.6^{b}$ & $177.4^{c}$ & $173.8^{c}$ & $<.001$ & 3.32 \\
\hline Water/Feed ratio & 1.87 & 1.77 & 1.71 & 1.67 & & \\
\hline European Efficiency Factor (EPEF) & $413^{b}$ & $417^{b}$ & $447^{a}$ & $428 \mathrm{ab}$ & 0.035 & 24.5 \\
\hline Footpad score (FPS) & $143^{a}$ & $110^{b}$ & $79^{c}$ & $39^{d}$ & $<.001$ & 28.1 \\
\hline
\end{tabular}

$a, b, c, d$ Values without a common superscript per row differ significantly $(P<0.05)$.

In line with the results from $11-35 d$, the protein conversion decreased with the decline of the crude protein content of the diet program. Broilers fed the CP-3\% diets had the best crude protein conversion, followed by broilers fed the $\mathrm{CP}-2 \%, \mathrm{CP}-1 \%$ and control diet program, respectively. Water intake decreased with the decrease of the crude protein content of the diet. However, the difference in water intake between broilers fed the CP- $2 \%$ diet program and those who received the CP-3\% diet program was not significant. As the feed intake was similar for all treatments, and the water intake was decreased with the decline of the crude protein content the water to feed ratio also decreased with the decrease of the crude protein. Broilers fed the CP- $2 \%$ diet program had the highest European Efficiency Factor (EPEF), which means that this treatment had the best overall performance results. The EPEF of the birds who received the $\mathrm{CP}-1 \%$ or $\mathrm{CP}-3 \%$ diet program did not differ from the birds in the control group.

Broilers fed the control diet program had the highest footpad score. This means that broilers of this group had the highest incidence and the most severe footpad lesions. The footpad score decreased with the decline of the crude protein content of the diet. The incidence of footpad lesions was in-line with the litter quality (see 3.5 ).

\subsection{Slaughter yields}

In Table 3.7 the slaughter yields per treatment on 35 days of age are given.

Table 3.7 Slaughter yields per treatment at day 35 of age

\begin{tabular}{|c|c|c|c|c|c|c|}
\hline & Control CP & $\mathrm{CP}-1 \%$ & CP-2\% & $\mathrm{CP}-3 \%$ & F-prob & LSD \\
\hline Live weight (LW, g) & 2446 & 2481 & 2488 & 2495 & 0.250 & 51.4 \\
\hline Carcass weight $(\mathrm{CW}, \mathrm{g})$ & 1615 & 1645 & 1648 & 1647 & 0.145 & 33.1 \\
\hline Carcass ( $\%$ of LW) & 66.0 & 66.3 & 66.2 & 66.0 & 0.402 & 0.46 \\
\hline Wing (g) & 166 & 169 & 168 & 167 & 0.270 & 3.3 \\
\hline Wing (\% of $\mathrm{CW})$ & $10.3^{\mathrm{a}}$ & $10.3^{a}$ & $10.2^{a b}$ & $10.1^{b}$ & 0.027 & 0.12 \\
\hline Leg (g) & $547^{b}$ & $555^{a b}$ & $557^{a b}$ & $564^{a}$ & 0.035 & 11.3 \\
\hline Leg $(\%$ of $C W)$ & $33.9^{b}$ & $33.8^{b}$ & $33.8^{b}$ & $34.3^{a}$ & 0.028 & 0.33 \\
\hline Back (g) & 243 & 246 & 251 & 253 & 0.051 & 7.3 \\
\hline Back (\% of CW) & $15.1^{\mathrm{b}}$ & $15.0^{b}$ & $15.2^{a b}$ & $15.3^{a}$ & 0.028 & 0.27 \\
\hline Breast meat (Filet) (g) & $520^{a b}$ & $532^{b}$ & $526^{a b}$ & $513^{a}$ & 0.046 & 13.5 \\
\hline Breast meat (Filet) (\% of CW) & $32.1^{\mathrm{ab}}$ & $32.3^{a}$ & $31.9^{b}$ & $31.2^{c}$ & $<.001$ & 0.39 \\
\hline
\end{tabular}

$a, b, c, d$ Values without a common superscript per row differ significantly $(P<0.05)$.

Providing broilers low protein diets had no significant effect on live weight, carcass weight or carcass yield. However, it did affect the wing, leg, back and breast meat yield. Broilers fed the CP-3\% diets program had a lower wing and breast meat yield but a higher leg and back yield compared with the control group. However, no differences between Control CP and CP-3\% were found in the weights of the wing, back and breast meat. Male broilers fed the CP-3\% diet program had a higher leg weight 
(thigh and drum) than those who received the control diet program. No differences in slaughter yields were found between broilers fed $\mathrm{CP}-1 \%$ or $\mathrm{CP}-2 \%$ and the control fed broilers. Although relative breast meat yield (\% of $\mathrm{CW}$ ) reduced with decreasing crude protein content, the absolute amount of breast yield $(\mathrm{g})$ of the low crude protein treatments was not lower compared to the control diet program.

\subsection{Litter quality and composition}

In Table 3.8 the visual litter quality (friability and wetness) and the litter composition at 35 day age is given. It can be concluded that the litter quality increased, indicating more friable and dryer litter, when the crude protein content of the diet decreased. Broilers fed the CP-3\% diet program had the best (visual) litter quality, followed by $\mathrm{CP}-2 \%$ and $\mathrm{CP}-1 \%$ diet program, and broilers fed the control diet program had the worst litter quality. No significant differences were found in visual litter quality between $\mathrm{CP}-1 \%$ and $\mathrm{CP}-2 \%$.

Table 3.8 Visual litter quality and dry matter, total nitrogen, ammonium nitrogen and $\mathrm{pH}$ of the litter on 35 days of age

\begin{tabular}{|c|c|c|c|c|c|c|}
\hline & Control CP & CP-1\% & CP- $2 \%$ & CP-3\% & F-prob & LSD \\
\hline Friability $^{1}$ & $3.3^{c}$ & $4.2^{\mathrm{b}}$ & $4.7^{b}$ & $6.1^{\mathrm{a}}$ & $<.001$ & 0.79 \\
\hline Wetness $^{2}$ & $2.7^{c}$ & $3.7^{b}$ & $4.4^{b}$ & $5.8^{a}$ & $<.001$ & 0.82 \\
\hline Dry matter (g/kg) & $387^{b}$ & $401^{a b}$ & $404^{a b}$ & $436^{a}$ & 0.033 & 32.7 \\
\hline Total-N (g/kg DM) & $43.7^{\mathrm{a}}$ & $42.6^{a}$ & $40.8^{a b}$ & $38.2^{b}$ & 0.002 & 2.78 \\
\hline Ammonia-N (g/kg DM) & $11.3^{a b}$ & $13.3^{a}$ & $12.7^{a b}$ & $11.1^{\mathrm{b}}$ & 0.026 & 1.65 \\
\hline $\mathrm{pH}$ & 6.5 & 6.8 & 7.1 & 7.0 & 0.122 & 0.53 \\
\hline
\end{tabular}

${ }^{1} 1-10: 1$ completely caked - 10: completely friable; ${ }^{2} 1-10: 1$ very wet -10 dry

The results of the visual litter quality correspond reasonably well with the dry matter (DM) contents of the litter. Broilers fed with the CP-3\% diet program had the highest DM-content of the litter. However, the DM-content of the CP-3\% group did only differ from the control, and not from the CP- $1 \%$ and CP$2 \%$ group.

Total- $\mathrm{N}$ of the litter of the control fed birds was significantly higher than $\mathrm{CP}-3 \%$, which means that more $\mathrm{N}$ was excreted. The total- $\mathrm{N}$ of the litter of $\mathrm{CP}-1 \%$ and $\mathrm{CP}-2 \%$ fed animals was in between and did not differ from either the control or the CP-3\% group. Litter ammonium-N content of broilers fed the $\mathrm{CP}-3 \%$ was significantly lower than $\mathrm{CP}-1 \%$ fed broilers, but it did not significantly differ from the control and $\mathrm{CP}-2 \%$ fed groups. No differences between dietary treatments were found in $\mathrm{pH}$ of the litter.

\subsection{Effect of low protein diets on economic parameters and carbon footprint}

In Figure 3.2 the effect of crude protein content of the diet on the carbon foot print and price of the feed is given. In Table 3.9 and 3.10, the revenues on farm (feed margin) and the revenues of chain (carcass value slaughter, based on the yield and prices of the different carcass parts) are provided, respectively. In appendix 7 the feed composition is given as well as the contribution of the individual feedstuffs used in the experimental diets on the carbon footprint. Data were generated from the FeedPrint database. The CFPAN tool and database FeedPrint calculates the carbon footprint of feed raw materials during their complete life cycle. This ranges from crop production, via processing of crop and animal products, compound feed production to utilization by the animal, including transport and storage between all steps of the production chain. For feed prices the prices of the feed ingredients from January 2017 were taken. 

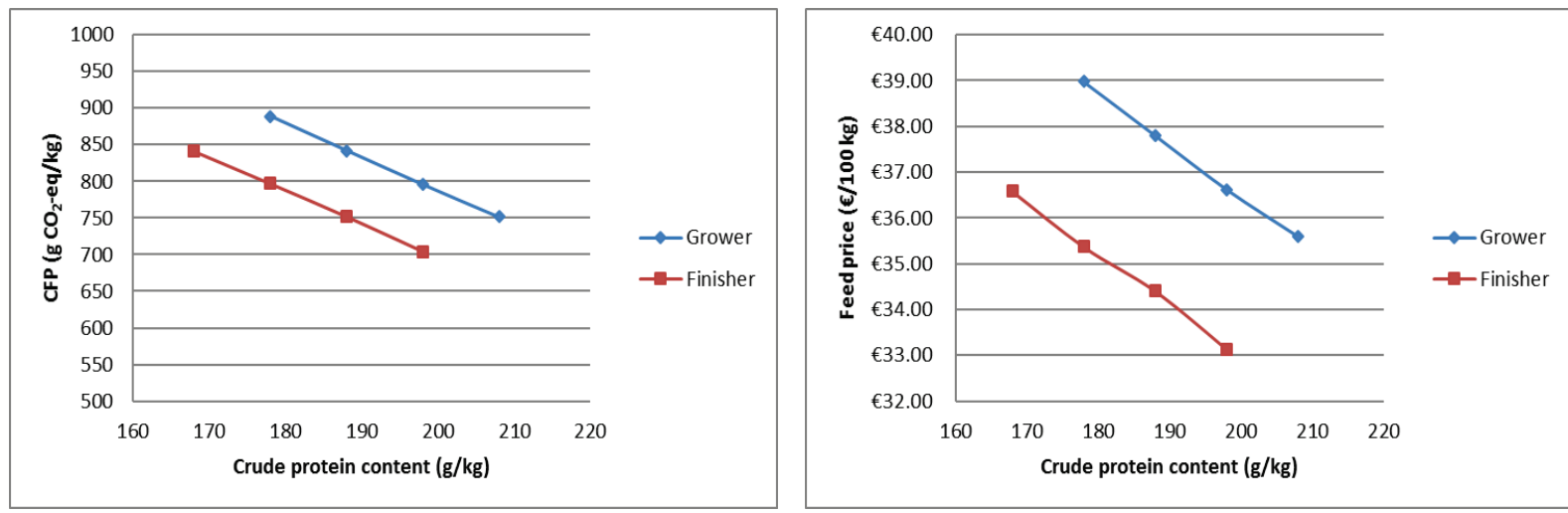

Figure 3.2 Effect of crude protein content of the experimental diets on the carbon foot print (left) and feed price (right) of the diets.

From this figure it can be concluded that a decrease of the crude protein content of broiler diets resulted in an increase of the feed costs as well in an increase of the carbon footprint (CFP). Each 0.8 percent lower crude protein leads to an increase of the CFP with $6 \%$, and to a $3 \%$ higher feed price.

Broilers fed the control diet program had the highest feed margin (Table 3.9) and broilers fed the CP$3 \%$ had the lowest feed margin. The feed margin of the broilers who received $\mathrm{CP}-1 \%$ or the $\mathrm{CP}-2 \%$ diet program were in between. The CP-3\% group had a 6.1 €cents per broiler delivered lower feed margin than the control group. The difference in feed margin between the $\mathrm{CP}-1 \%$ and $\mathrm{CP}-2 \%$ group with the control group was 2.6 and 2.4 €cents per delivered broiler, respectively.

Table 3.9 Feed margin at farm level per treatment at day 35 of age.

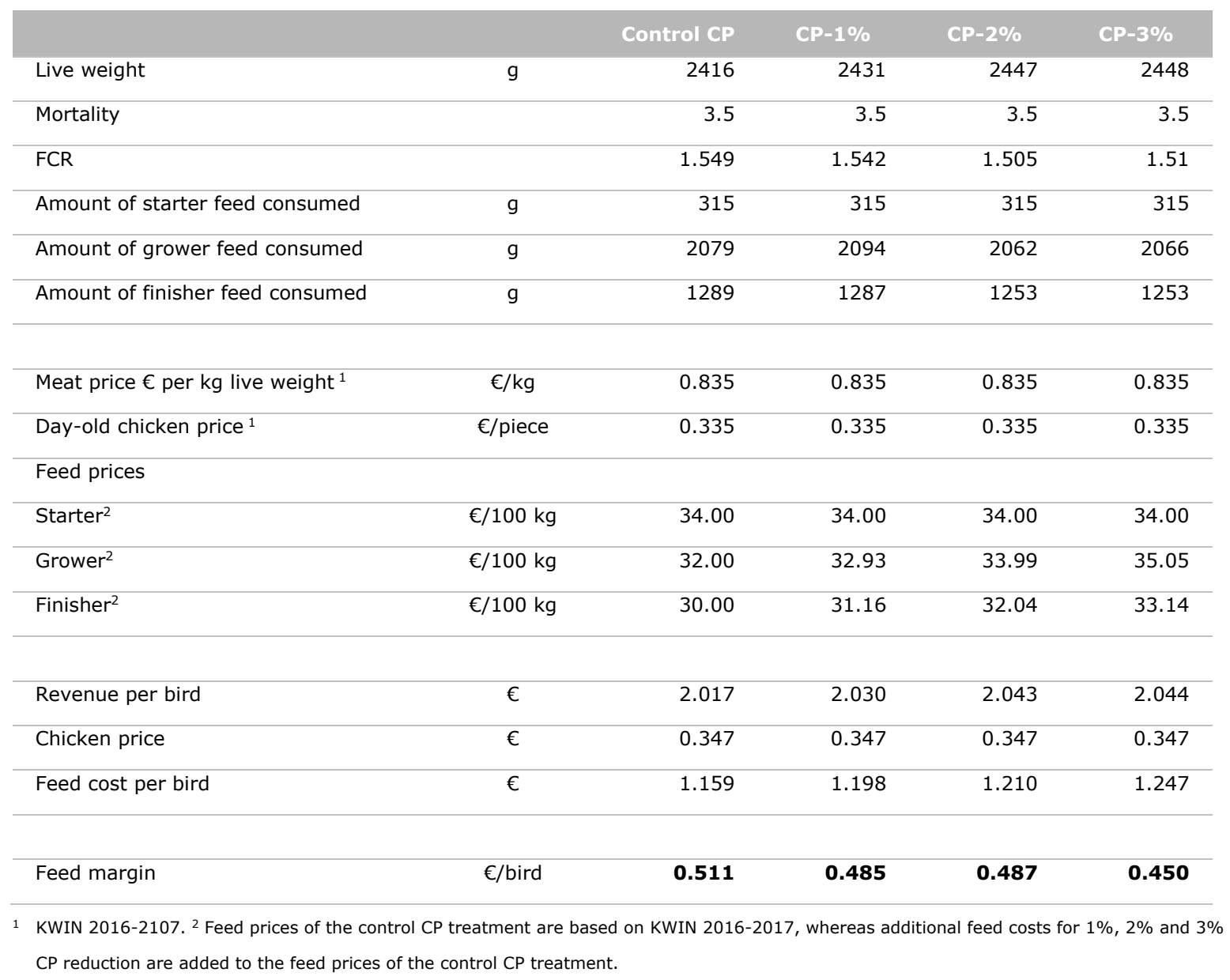


The higher feed price of the low crude protein diets was related to the extra supplementation of free amino acids in these diets. Lowering the crude protein content of the grower diet with 1,2 or $3 \%$ increased the feed price with 2.9, 6.2 and 9.5\%, respectively. For the finisher diet this was 3.9, 6.8 and $10.5 \%$, respectively. The improved performance of the broilers fed the CP- $2 \%$ or $\mathrm{CP}-3 \%$ diet programs could not compensate for the increased feed costs, overall resulting in lower feed margins of these groups compared with the control fed broilers.

In Table 3.10, the revenues of chain are provided, taking into account the economic value of the wings, legs, back and breast meat. Providing low protein diets, supplemented with free amino acids, to broilers resulted in similar (CP-3\%) or even higher (in case of $\mathrm{CP}-1 \%$ or $\mathrm{CP}-2 \%$ ) chain results. Broilers fed the control diet program had a similar chain revenue compared to broilers who received $\mathrm{CP}-3 \%$ diet program ( $€ 4.388$ vs. $€ 4.392$ ). Compared with the $\mathrm{CP}-1 \%$ and $\mathrm{CP}-2 \%$ groups, the chain result of the control group was respectively $8.9 €$ cents and 6.0€cents lower. This difference was largely attributable to the higher leg and breast meat weight of the broilers fed the $\mathrm{CP}-1 \%$ or $\mathrm{CP}-2 \%$ diet programs.

Table 3.10 Revenues of chain per treatment at day 35 of age.

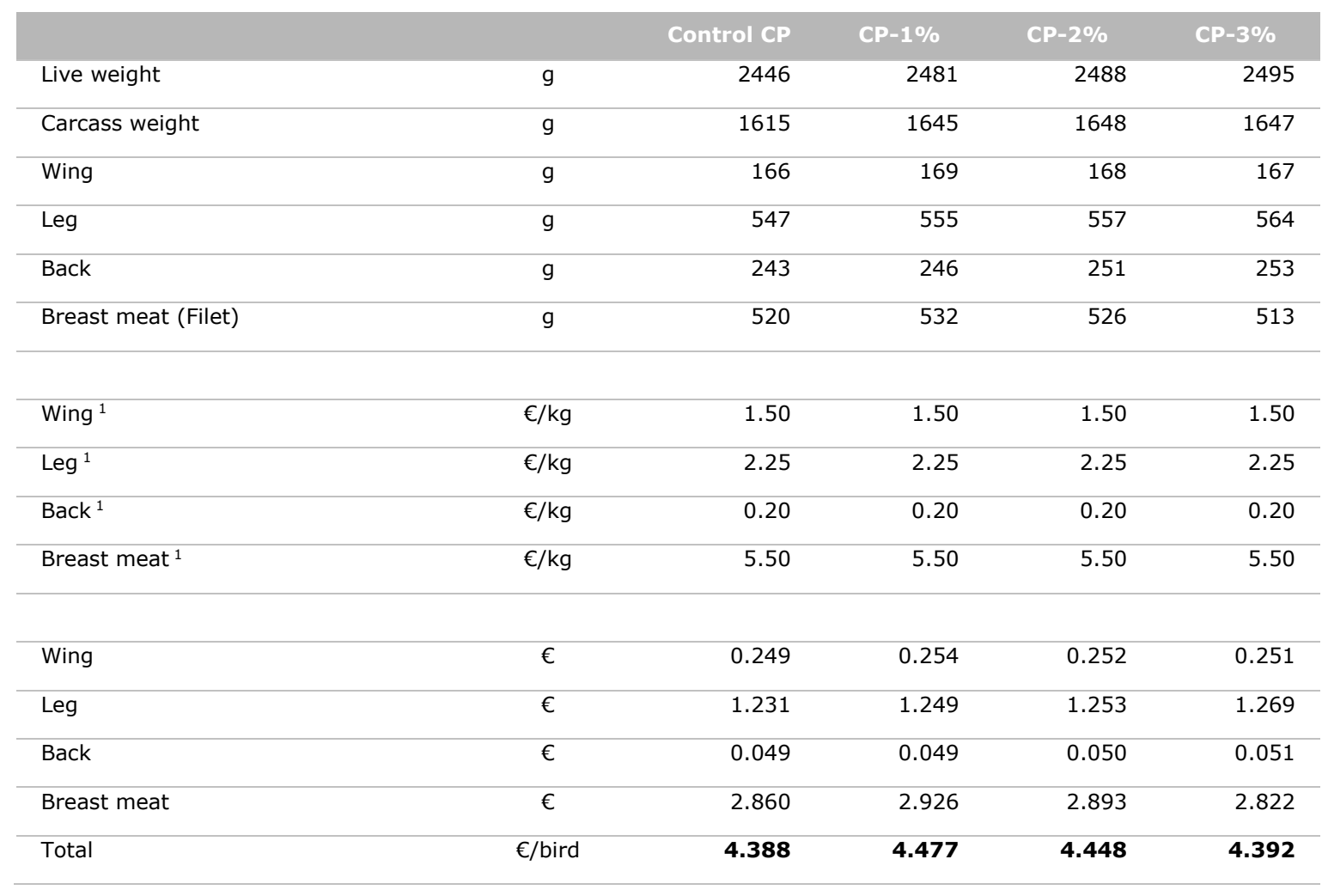

1 BedrijfsWijzer Pluimvee 


\section{Discussion}

Providing broilers with low protein diets often results, even if they were supplemented with free amino acids, in declined performance results (e.g. Ferguson et al., 1998a,b; Bregendahl et al, 2002).

However, the growth performance results in the present study of the broilers fed the AA supplemented low protein diet programs were similar or even better compared with broilers fed the control diet program.

In the present experiment the obtained growth performance results of broilers fed the low protein diets were better than for the control fed broilers. This phenomenon has not often been observed. Mostly, similar or deteriorated growth performance is observed with low-protein diets. A deteriorated litter quality and a higher incidence of footpad lesions, consequently resulting in less locomotion and reduced feed intake, not observed in the present trial, of the control fed birds, thermal discomfort, could be reasons of the decreased growth performance results of the control fed birds. De Jong et al. (2014) found decreased growth performance results of birds kept on wet litter and had a high incidence of severe footpad lesions. Broilers kept on dry and friable litter had better growth performance results than those who were kept on wet litter.

Besides, it is well known that high-protein diets might have negative effects on gut health and performance (Apajalahti and Vienola, 2016; Qaisrani et al, 2015). Ileal bypass protein is subject to fermentation by putrefactive bacteria in the caecum. Putrefaction produces many harmful and toxic compounds, which in high concentrations may have adverse effects on chicken growth and performance. The protein fermentation products include toxic components like amines, indoles, phenols, cresol and ammonia, which in high concentrations may have adverse effects on chicken growth and performance (Apajalahti and Vienola, 2016). Reduction of ileal bypass protein potentially also reduce production of toxic protein fermentation metabolites in the caeca.

Moreover, the inclusion of free glycine in the diets in the present study, thereby covering the glycine and serine requirement, may be a solid explanation of the obtained similar (CP-1\% and CP-3\% diet program) or even better ( $\mathrm{CP}-2 \%$ diet program) growth performance results of the low protein groups. According to Ospina-Rojas et al. (2013) supplemental glycine may be essential to support maximum performance for broiler chickens when they are fed diets based on vegetable ingredients and with low protein levels.

Broiler chickens are constantly in contact with the litter. It is well known that increased litter moisture increases the risk for skin dermatitis (footpad lesions, hock burns and dermatitis of the skin on the chest), e.g. Greene et al. (1985) and Martland (1985). In addition, broilers suffering from pain caused by (severe) footpad dermatitis (Martland, 1985) and possibly also from dermatitis on the hocks and breast may be less eager to go to the feeders and drinkers and thus may show less weight gain as broilers having no or mild footpad dermatitis. De Jong et al. (2014) found that wet litter not only induces contact dermatitis (like footpad lesions, hock burns, breast blisters), it had also negative effects on birds locomotion, growth performance results and carcass yield. According to De Jong et al. (2014) the deteriorated growth performance results were caused by the fact that birds having severe footpad lesions (and possibly also from hock burns and/or breast dermatitis) walk less, because they suffer from pain. As a result of this they may be less eager to go to the feeders and drinkers. Also wet litter feels cold which resulted in more huddling and thermal discomfort. It could well be that the deteriorated growth performance results of broilers fed the control diet were caused by the deteriorated litter quality. Broilers of the control group suffer more from footpad lesions compared to broilers fed the low protein diet programs. Also the deteriorated litter quality in the control group may also have led to some thermal discomfort of the birds, which may also have affected their growth performance results (especially FCR) negatively. 
The incidence of footpad lesions in the current study decreased linearly with the decline of the dietary crude protein content. It is well known that the most important factor causing FPD is considered to be wet litter (Shepherd and Fairchild, 2010). In the current study the observed differences in litter quality are good in line with the found footpad scores. Broilers fed the control diet program had the worst litter quality (less friable and less dry) and the highest footpad scores.

Reducing dietary crude protein resulted in a decrease of the litter moisture content and nitrogen content. These results were in line with the findings of Kamran et al. (2010) and Ferguson et al. (1998a), but not completely in line with Moran et al. (1992), Elwinger and Svensson (1996), Ferguson et al. (1998b), Khajali and Moghaddam (2006) and Ospina-Rojas et al. (2012), who also noted a decrease in the nitrogen content, but no change in the moisture content of the litter. Ferguson et al (1998a) found with a $2 \%$ reduction in dietary crude protein a decreased litter ammonia and nitrogen concentrations of 31 and $16.5 \%$, respectively. In this trial the total nitrogen content of the low protein diets were only $2.5 \%, 6.6 \%$ and $12.6 \%$ lower than the control group, for $\mathrm{CP}-1 \%, \mathrm{CP}-2 \%$ and $\mathrm{CP}-3 \%$ respectively. However, only the $\mathrm{N}$-content of the litter of the $\mathrm{CP}-3 \%$ fed broilers differed significantly from the control. The measured reduction in total nitrogen in this trial was lower than in the study of Ferguson et al (1998a). In this trial the provision of low protein diets did not result in a reduction of the ammonium $\mathrm{N}$ content of the litter. This was not in-line with the expectation. It was expected that providing low protein diets to broilers would result in a lower ammonium nitrogen content of the litter, but in this trial none of the low protein groups had a significant lower ammonium-N compared with the control group. In general, lower dietary crude protein levels seen to reduce the $\mathrm{N}$ content of the litter (Elwinger and Svensson, 1996; Fergusson et al., 1998a,b; Khajali and Moghaddam, 2006 and OspinaRojas et al., 2012). Our results confirm that, even in a multiphase feeding program, the excretion of $\mathrm{N}$ was decreased with reduced levels of dietary crude protein.

As expected, the reduction in dietary crude protein content affected the daily water intake of the broilers and consequently the DM content of the litter. The reduction in water consumption by lowering the dietary crude protein content is a well-known effect (Bailey, 1999). A higher protein intake increases the amount of metabolites, e.g. uric acid and potassium, that have to be excreted in urine, and water is necessary to excrete nitrogenous waste products from the protein metabolism. Because of the lower water intake in the low-protein diets fed birds, also the water/feed ratio decreased, which was in line with findings of Elwinger and Svensson (1996). Despite the lower water intake of the broilers fed the low protein diets, the litter dry matter was not influenced. Although the findings regarding water intake met our expectations, it should be noticed that water intake was not measured per pen but per treatment per two rows of pens, indicating that no hard conclusion can be drawn from the observed lower water / feed ratio. However, feeding low protein diets does not always affect litter moisture content. Elwinger and Svensson (1996), Ferguson et al. (1998b), Hernandez et al. (2013) and Ospina-Rojas et al. (2014) did not find any effect in their studies on litter moisture content. Differences in season, housing and management (in particular ventilation) could explain absence of effects on litter moisture content.

In the current study, no effects on the litter acidity or $\mathrm{pH}$ of the litter were detected for the dietary crude protein content, which is in agreement with previous studies (Elwinger and Svensson, 1996; Ferguson et al., 1998b; Hernandez et al., 2013 and Ospina-Rojas et al., 2014). However, in contrast to our study, Ferguson et al (1998a) reported a decrease in litter pH with low protein diets.

Broilers fed the CP-3\% diets program had a lower wing and breast meat yield but a higher leg and back yield compared with the control group. However, due to the higher body weight at slaughter age the weight of the different parts did not differ from the control fed broilers. Feeding AA supplemented diets with up to two percent lower crude protein did not affect the slaughter yields. These results are in line with Ospina-Rojas et al (2014), who also found no differences in slaughter yields (and growth performance results) in diets with a $3 \%$ reduction in crude protein AA supplemented diets. According to Ospina-Rojas it is important that glycine and arginine is added to low protein diets, accompanied by the supplementation of valine and isoleucine, besides lysine, methionine and threonine, to maintain adequate slaughter yields. 
Despite the lower SBM content in the low protein diets the carbon foot print (CFP) was not lower compared to the control diet. The use of free amino acids, especially threonine, is the main reason for the higher CFP. For example the CFP for free L-lysine, DL-methionine, L-tryptophan, L-arginine, Lisoleucine, L-threonine is $6030,5490,9500,9500,9500$ and $16978 \mathrm{~g} \mathrm{CO}_{2}$-eq/ $\mathrm{kg}$, respectively (FeedPrint database). Marinussen and Kool (2010) describe the environmental impact of the production of free amino acids L-lysine, D, L-methionine and L-threonine. For the production of Lthreonine, high quantities of sulphate compounds are required, which significantly contribute to the acidification of the environment. This explains the very high CFP value of L-threonine. 


\section{Conclusions}

From this study, in which in the grower and finisher phase $(11-35 d)$ diets with a 1,2 or $3 \%$ lower crude protein content but similar digestible amino acids contents of the first nine limiting amino acids including glycine were provided, thereby reducing the soybean meal content up to $10 \%$, it can be concluded that:

Providing broilers diets with up to a $3 \%$ lower crude protein content but similar digestible AA in the grower and finisher phase resulted in similar growth performance or even better growth performance results compared to broilers fed a control diet program with a dietary protein content in the grower and finisher phase of 208 and $198 \mathrm{~g} / \mathrm{kg}$, respectively. The best overall performance results were obtained with the $\mathrm{CP}-2 \%$ diet program.

Over the entire experimental period $(0-35 d)$ none of the low protein diet programs affected body weight gain, feed intake or mortality. However, the crude protein efficiency improved with the decline of the crude protein content of the diet. Broilers fed the $\mathrm{CP}-1 \%$ diet program had numerically but not significantly a better feed conversion ratio compared to the control fed birds. Broilers fed the CP- $2 \%$ or $\mathrm{CP}-3 \%$ diet program had a statistically improved feed conversion ratio.

Broilers fed the low protein diet programs had a lower water intake, which resulted in a better litter quality and less severe footpad lesions, thus a lower footpad score.

Providing broilers diets with up to a $3 \%$ lower crude protein content but similar digestible AA hardly influenced the slaughter yield. Only the breast meat yield of broilers fed the diet with $3 \%$ lower crude protein content was lower, while the breast meat weight did not differ.

Providing low protein diets resulted in an increase of the carbon footprint as well in an increase of the feed price, whereas feed margin was reduced in the low crude protein diets.

Overall it can be concluded that supplementation of free AA to the diet allows to reduce soybean meal content of broiler diets by $10 \%$, thereby reducing crude protein content. Feeding broilers diets with a $3 \%$ lower crude protein content did not result in adverse effects on growth performance results and slaughter yields if they are supplemented, with sufficient lysine, and in the recommended ratio to lysine, with free methionine, threonine, arginine, isoleucine, valine and glycine. The former could be a possible measure to reduce the amount / share of non-European protein in the broiler diets. However, replacing (partly) non-European protein by European protein in combination with an increased use of free amino acids will increase the feed costs and carbon foot print and reduce feed margin.

How further?

Currently, free glycine is not registered for use as free amino acid, which hampers the implementation of low crude protein diets in broiler production. Threonine (Thr) is a known precursor of glycine (Gly) via the Thr dehydrogenase and aldolase pathways (Davis and Austic, 1982). It was demonstrated before that Thr could spare the Gly requirement (Ospina-Rojas et al., 2013; Siegert et al., 2015). In an upcoming trial, the responses of broilers to graded levels of Gly in the diets with respect to growth performance, slaughter yields, litter quality and footpad lesions will be investigated in low crude protein diets. In addition, in this study the glycine sparing effect of threonine will be evaluated. 


\section{References}

Aftab, U., M. Ashraf and Z. Jiang, 2006. Low protein diets for broilers. World's Poultry Sci. J. 62:688701.

Aletor, V.A., I.I. Hamid, E. Nieß and E. Pfeffer, 2000. Low-protein amino acid supplemented diets in broilers chickens: effects on performance, carcass characteristics, whole-body composition and efficiencies of nutrient utilization. J.Sci. Food Agric. 80:547-554.

Apajalahti, J., and K. Vienola, 2016. Interaction between chicken intestinal microbiota and protein digestion. Anim. Feed Sci. Technol. 221:323-330.

Aviagen, 2014. Ross 308 Broiler Performance Objectives.

Bailey M, 1999. The water requirements of poultry. In: Recent developments in poultry nutrition 2 (Wiseman J, Garnsworthy PC, eds). Nottingham Univ. Press, UK. pp: 321-335.

Berg, C., 1998. Footpad dermatitis in broilers and turkeys. Doctoral diss. Dept. of Animal Environment and Health, SLU. Acta Universitatis Agriculturae Sueciae, Sweden.

Berres, J., S.L. Vieira, W.A. Dozier III, M.E.M. Cortês, R. de Barros, E.T. Nogueira, and M. Kutschenko, 2010. Broiler responses to reduced-protein diets supplemented with valine, isoleucine, glycine, and glutamic acid. J. Appl. Poult. Res. 19:68-79.

Bregendahl, K., J.L. Sell and D.R. Zimmerman, 2002. Effect of low-protein diets on growth performance and body composition of broiler chicks. Poultry Sci. 81:1156-1167.

CVB, 2012. Livestock feed table (Tabellenboek Veevoeding); Tables values poultry nutrition. 2012. Centraal Veevoederbureau, Lelystad, the Netherlands.

Davis, A.T., and R.E. Austic, 1982. Threonine imbalance and the threonine requirement of the chicken. J. Nutr. 112(11):2170-2176.

Dean, D.W., T.D. Bidner and L.L. Southern, 2006. Glycine supplementation to low protein, amino acidsupplemented diets supports optimal performance of broiler chicks. Poultry Sci. 85:288-296.

De Jong I.C., H. Gunnink and J. van Harn, 2014. Wet litter not only induces footpad dermatitis but also reduces overall welfare, technical performance, and carcass yield in broiler chickens. J. Appl. Poult. Res. $23: 51-58$.

Elwinger K. and L. Svensson, 1996. Effect of dietary protein content, litter and drinker type on ammonia emission from broiler houses. J Agric Eng Res 64: 197-208.

Euractiv, 2011. Meps want to end 'protein deficit' for eu livestock.

FAO, 2006. World agriculture: Towards 2030/2050. Global Perspective Studies Unit. Food and Agriculture Organization of the United Nations. Rome, June 2006.

FEFAC, 2015. Feed \& food; statistical yearbook 2014. http://www.fefac.eu/files/62107.pdf.

Ferguson, N.S., R.S. Gates, J.L. Taraba, A.H. Cantor, A.J. Pescatore, M.J. Ford and D.J. Burnham, 1998a. The effect of dietary crude protein on growth, ammonia concentration, and litter composition in broilers. Poultry Sci. 77:1481-1487.

Ferguson N.S., R.S. Gates, J.L. Taraba, A.H. Cantor, A.J. Pescatore, M.L. Straw, M.J. Ford and D.J. Burnham, 1998b. The effect of dietary protein and phosphorus on ammonia concentration and litter composition in broilers. Poult Sci 77: 1085-1093.

GenStat 18 Committee, 2015. Genstat 18th Reference Manual: Release 1. Clarendon Press, Oxford, UK.

Greene, J.A., R.M. McCracken, R.T. Evans, 1985. A contact dermatitis of broilers - Clinical and pathological findings. Avian Pathol. 14:23-38.

Harn, J. van, J.H. van Middelkoop, 1996. Invloed van eiwitverlaging in voer op resultaten en stikstofuitscheiding bij vleeskuikens. Praktijkonderzoek 96/2.

Hernandez, F., M.D. Megias, J. Orengo, S. Martinez, M.J. Lopez and J. Madrid, 2013. Effect of dietary protein level on retention of nutrients, growth performance, litter composition and NH3 emission using a multi-phase feeding programme in broilers. Spanish Journal of Agricultural Research 2013 11(3): 736-746

Kerr, B.J. and M.T. Kidd, 1999. Amino acid supplementation of low-protein broiler diets: 2. Formulation on an ideal amino acid basis. J. Appl. Poultry Res. 8:310-320.

Kamran, Z., M. Sarwar, M.U. Nisa, M.A. Nadeem and S. Mahmood, 2010. Effect of low levels of dietary crude protein with constant metabolizable energy on nitrogen excretion, litter composition and blood parameters of broilers. Int. J. Agric. Biol., 12: 401-405. 
Khajali, F. and H.N. Moghaddam, 2006. Methionine of low protein broiler diets: Influence upon growth performance and efficiency of protein utilization. Int. J. Poult. Sci., 5: 569-573

Kidd, M.T., B.J. Kerr, J.D. Firman and S.D. Boling, 1996. Growth and carcass characteristics of broilers fed low-protein, threonine-supplemented diets. J. Appl. Poultry Res. 5: 180-190.

KWIN-V 2016-2017. Handboek Kwantitatieve Informatie Veehouderij 2016-2017.

Marinussen, M., and A. Kool. 2010. Environmental impacts of synthetic amino acid production. Blonk Milieu Advies BV, Gouda, The Netherlands. http://www.blonkconsultants.nl/wpcontent/uploads/2016/06/amino-acids.pdf

Martland, M.F., 1985. Ulcerative dermatitis in broiler chickens - The effect of wet litter. Avian Pathol. $14: 353-64$.

Moran, E.T. Jr., R.D. Bushong and S.F. Bilgili, 1992. Reducing dietary crude protein for broilers, while satisfying amino acids requirements by least cost formulations: Live performance, litter composition and yield of fast food carcass cuts at six weeks. Poult. Sci., 71: 1687-1694.

Nahm, K.H., 2002. Efficient feed nutrient utilization to reduce pollutants in poultry and swine manure. Critical Rev. Environ. Sci. Tech. 32(1):1-16.

Namroud, N.F., M. Shivazad and M. Zaghari, 2008. Effects of fortifying low crude protein diet with crystalline amino acids on performance, blood ammonia level, and excreta characteristics of broiler chicks. Poultry Sci. 87:2250-2258.

Ospina-Rojas, I.C., A.E. Murakami, C. Eyng, R.V. Nunes, C.R. Duarte and M.D. Vargas, 2012. Commercially available amino acid supplementation of low-protein diets for broiler chickens with different ratios of digestible glycine+serine:lysine. Poultry Science, 91: 3148-3155.

Ospina-Rojas, I.C., A.E. Murakami, C.A. Oliveira and A.F.Q.G. Guerra, 2013. Supplemental glycine and threonine effects on performance, intestinal mucosa development, and nutrient utilization of growing broiler chickens. Poultry Science, 92: 2724-2731.

Ospina-Rojas, I.C., A.E. Murakami, C.R.A. Duarte, C. Eyng, C.A.L. Oliveira and V. Janeiro, 2014. Valine, isoleucine, arginine and glycine supplementation of low-protein diets for broiler chickens during the starter and grower phases, British Poultry Science, 55:6, 766-773

Qaisrani, S.N., M.M. van Krimpen, R.P. Kwakkel, M.W.A. Verstegen, and W.H. Hendriks, 2015. Dietary factors affecting hindgut protein fermentation in broilers: A review. Worlds Poult. Sci. J. 71(1):139-160.

Rockström, J., W. Steffen, K. Noone, Å. Persson, F.S. Chapin, E.F. Lambin, T.M. Lenton, M. Scheffer, C. Folke, H.J. Schellnhuber, B. Nykvist, C.A. De Wit, T. Hughes, S. Van Der Leeuw, H. Rodhe, S. Sörlin, P.K. Snyder, R. Costanza, U. Svedin, M. Falkenmark, L. Karlberg, R.W. Corell, V.J. Fabry, J. Hansen, B. Walker, D. Liverman, K. Richardson, P. Crutzen and J.A. Foley, 2009. A safe operating space for humanity. Nature 461(7263):472-475.

Shepherd, E.M., and B.D. Fairchild, 2010. Footpad dermatitis in poultry. Poult. Sci. 89:2043-2051.

Siegert, W., H. Ahmadi, A. Helmbrecht, and M. Rodehutscord, 2015. A quantitative study of the interactive effects of glycine and serine with threonine and choline on growth performance in broilers. Poultry Science 94(7):1557-1568.

Van Gelder, J.W. and B. Kuepper, 2012. Verdeling van de economische waarde van de mondiale sojateelt. Edited by Profundo. Amsterdam.

Veldkamp, T., R. Dekker, A. Smit-Heinsbroek, A. van der Lee, A.J.M. Jansman, 2015. Effect of isoenergetic exchange of dietary fat and starch on growth performance and body composition of broilers - Experiment 2. Wageningen, Wageningen UR (University \& Research centre) Livestock Research, Livestock Research Report X (in press).

Vellinga, Th.V., H. Blonk, M. Marinussen, W.J. van Zeist and D.A.J. Starmans, D.A.J., 2013. Methodology used in FeedPrint: a tool quantifying greenhouse gas emissions of feed production and utilization. Wageningen UR Livestock Research Report no. 674.

Vermeij I. and J. Kanis, 2005. Bedrijfswijzer Pluimvee geeft u het antwoord: wijziging zinvol en haalbaar?. Pluimveehouderij 35: p25.

Waguespack, A.M., S. Powell, T.D. Bidner, R.L. Payne and L.L Southern, 2009. Effect of incremental levels of L-lysine and determination of the limiting amino acids in low crude protein corn-soybean meal diets for broilers. Poultry Science, 88: 1216-1226.

Waldroup, P.W., R.J. Mitchell, J.R. Payne and K.R. Hazen, 1976. Performance of chicks fed diets formulated to minimize excess levels of essential amino acids. Poultry Sci. 55: 243-253.

WNF 2011. Http://www.Wnf.Nl/nl/wat_wnf_doet/thema_s/bossen/ontbossing/sojateelt/. 


\section{Appendix 1 Lay-out of the experimental facility}

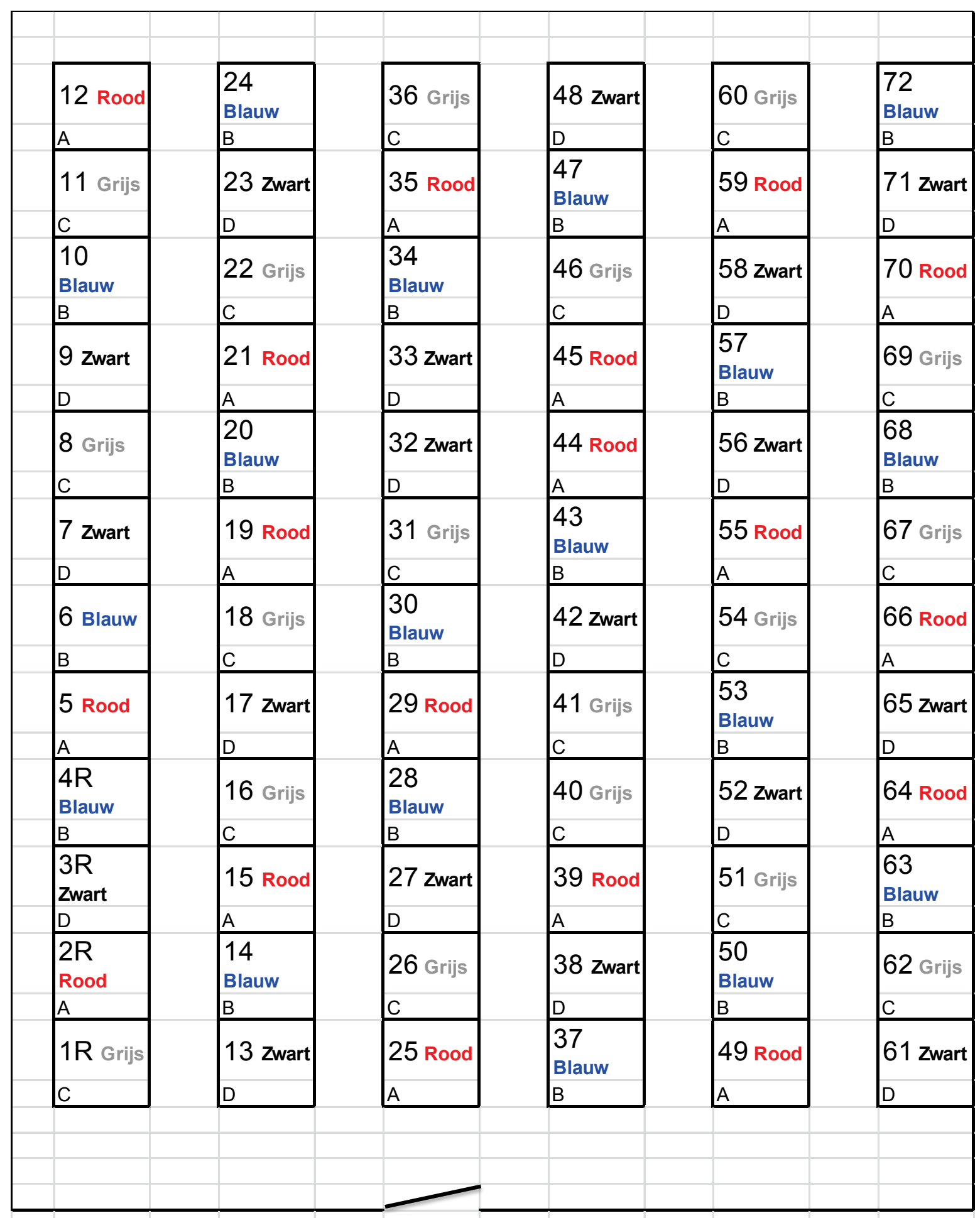

Number $1,2,3, \ldots .72=$ Pen number

Rood, Blauw, Grijs en Zwart: different colours of the treatments.

Pen $1 R, 2 R, 3 R$ en $4 R$ : reserve pens 


\section{Appendix 2 Feed composition and calcu- lated nutrients of the diets}

\begin{tabular}{|c|c|c|c|c|c|c|c|c|c|c|}
\hline & & \multirow{2}{*}{$\begin{array}{c}\text { Starter } \\
\text { diet }\end{array}$} & \multicolumn{4}{|c|}{ Grower diets } & \multicolumn{4}{|c|}{ Finisher diets } \\
\hline & & & Contr & $-1 \%$ & $-2 \%$ & $-3 \%$ & Contr & $-1 \%$ & $-2 \%$ & $-3 \%$ \\
\hline \multicolumn{11}{|l|}{ Raw materials } \\
\hline Wheat & $\%$ & 30.87 & 37.29 & 30.00 & 30.00 & 30.00 & 39.64 & 30.00 & 30.00 & 30.29 \\
\hline Corn & $\%$ & 25.00 & 18.80 & 29.04 & 32.75 & 36.51 & 20.56 & 33.02 & 36.49 & 40.00 \\
\hline Soybean meal HiPro nGMO & $\%$ & 30.47 & 27.34 & 24.84 & 21.07 & 17.30 & 24.99 & 22.55 & 18.41 & 14.62 \\
\hline Rapeseed meal 00 & $\%$ & 3.00 & 5.00 & 4.96 & 5.00 & 5.00 & 4.28 & 4.40 & 5.00 & 5.00 \\
\hline Palmoil crude & $\%$ & 1.54 & 2.71 & 2.45 & 2.19 & 1.51 & 2.51 & 2.25 & 1.68 & 1.01 \\
\hline Soya lecithin & $\%$ & 1.00 & 1.00 & 1.00 & 1.00 & 1.00 & 1.00 & 1.00 & 1.00 & 1.00 \\
\hline Soya oil & $\%$ & 0.92 & 1.51 & 0.87 & 0.50 & 0.50 & 1.22 & 0.50 & 0.50 & 0.50 \\
\hline Lauric fatty acids & $\%$ & 0.50 & 0.50 & 0.50 & 0.50 & 0.50 & 0.50 & 0.50 & 0.50 & 0.50 \\
\hline Limestone & $\%$ & 0.25 & -- & -- & -- & -- & 0.25 & 0.25 & 0.25 & 0.26 \\
\hline L-Lysine $\mathrm{HCl}$ & $\%$ & 0.22 & 0.16 & 0.24 & 0.36 & 0.48 & 0.16 & 0.24 & 0.36 & 0.47 \\
\hline Sodium bicarbonate & $\%$ & 0.28 & 0.21 & 0.25 & 0.31 & 0.39 & 0.24 & 0.28 & 0.34 & 0.41 \\
\hline DL-methionine & $\%$ & 0.28 & 0.23 & 0.25 & 0.29 & 0.32 & 0.21 & 0.24 & 0.27 & 0.31 \\
\hline Sodium chloride & $\%$ & 0.11 & 0.13 & 0.10 & 0.06 & -- & 0.12 & 0.09 & 0.05 & -- \\
\hline L-threonine & $\%$ & 0.09 & 0.05 & 0.09 & 0.14 & 0.19 & 0.05 & 0.08 & 0.14 & 0.19 \\
\hline L-Valine 98 & $\%$ & 0.07 & 0.02 & 0.07 & 0.14 & 0.21 & 0.02 & 0.07 & 0.14 & 0.20 \\
\hline Xylanase $6,25 \%$ & $\%$ & 0.10 & 0.10 & 0.10 & 0.10 & 0.10 & 0.10 & 0.10 & 0.10 & 0.10 \\
\hline Phyzyme XP 5000L & $\%$ & 0.01 & 0.01 & 0.01 & 0.01 & 0.01 & 0.01 & 0.01 & 0.01 & 0.01 \\
\hline Oat hulls & $\%$ & 2.00 & 2.00 & 2.00 & 2.00 & 2.00 & 2.00 & 2.00 & 2.00 & 2.00 \\
\hline Mono calcium phosphate & $\%$ & 0.99 & 0.66 & 0.69 & 0.76 & 0.82 & 0.15 & 0.19 & 0.22 & 0.26 \\
\hline L-Arginine & $\%$ & -- & -- & 0.08 & 0.19 & 0.30 & -- & 0.08 & 0.19 & 0.30 \\
\hline L-Isoleucine & $\%$ & -- & -- & 0.04 & 0.11 & 0.18 & -- & 0.04 & 0.11 & 0.18 \\
\hline L-Glycine & $\%$ & -- & -- & 0.09 & 0.21 & 0.34 & -- & 0.09 & 0.22 & 0.34 \\
\hline Tryptophan & $\%$ & -- & -- & 0.02 & 0.04 & 0.06 & -- & 0.02 & 0.04 & 0.06 \\
\hline VM VLK 0-20 dgn 8754 & $\%$ & 2.00 & 2.00 & 2.00 & 2.00 & 2.00 & -- & -- & -- & -- \\
\hline VM VLK 20-40 dgn. & $\%$ & -- & -- & -- & -- & -- & 2.00 & 2.00 & 2.00 & 2.00 \\
\hline VM Maxiban $0,3 \%$ & $\%$ & 0.30 & 0.30 & 0.30 & 0.30 & 0.30 & -- & -- & -- & -- \\
\hline \multicolumn{11}{|l|}{ Nutrients } \\
\hline AMEn broiler & $\mathrm{kcal} / \mathrm{kg}$ & 2900 & 3000 & 3000 & 3000 & 3000 & 3025 & 3025 & 3025 & 3025 \\
\hline Crude protein & $\mathrm{g} / \mathrm{kg}$ & 216 & 208 & 198 & 188 & 178 & 198 & 188 & 178 & 168 \\
\hline Crude fat & $\mathrm{g} / \mathrm{kg}$ & 67 & 83 & 76 & 70 & 64 & 79 & 71 & 66 & 60 \\
\hline Crude fibre & $\mathrm{g} / \mathrm{kg}$ & 35 & 37 & 36 & 35 & 34 & 35 & 35 & 34 & 34 \\
\hline Crude ash & $\mathrm{g} / \mathrm{kg}$ & 54 & 48 & 47 & 46 & 44 & 43 & 42 & 40 & 39 \\
\hline Starch Brunt & $\mathrm{g} / \mathrm{kg}$ & 353 & 351 & 373 & 397 & 421 & 376 & 399 & 421 & 445 \\
\hline Calcium & $\mathrm{g} / \mathrm{kg}$ & 8.0 & 6.5 & 6.5 & 6.5 & 6.5 & 5.5 & 5.5 & 5.5 & 5.5 \\
\hline Phosphorus & $\mathrm{g} / \mathrm{kg}$ & 6.2 & 5.5 & 5.5 & 5.5 & 5.5 & 4.2 & 4.2 & 4.2 & 4.1 \\
\hline Sodium & $\mathrm{g} / \mathrm{kg}$ & 1.4 & 1.3 & 1.3 & 1.3 & 1.3 & 1.3 & 1.3 & 1.3 & 1.3 \\
\hline Potassium & $\mathrm{g} / \mathrm{kg}$ & 9.7 & 9.3 & 8.7 & 8.0 & 7.2 & 8.7 & 8.2 & 7.5 & 6.7 \\
\hline Chloride & $\mathrm{g} / \mathrm{kg}$ & 1.5 & 1.5 & 1.5 & 1.5 & 1.4 & 1.5 & 1.5 & 1.5 & 1.5 \\
\hline $\mathrm{dEB}$ & meq & 260 & 245 & 232 & 213 & 196 & 236 & 223 & 203 & 185 \\
\hline 6-Phytase E4a1640 & $\mathrm{ftu}$ & 500 & 500 & 500 & 500 & 500 & 500 & 500 & 500 & 500 \\
\hline Dig.lysine & $\mathrm{g} / \mathrm{kg}$ & 11.5 & 10.5 & 10.5 & 10.5 & 10.5 & 9.9 & 9.9 & 9.9 & 9.9 \\
\hline Dig.methionine & $\mathrm{g} / \mathrm{kg}$ & 5.6 & 5.0 & 5.1 & 5.3 & 5.5 & 4.7 & 4.9 & 5.1 & 5.2 \\
\hline Dig.met+cys & $\mathrm{g} / \mathrm{kg}$ & 8.5 & 7.9 & 7.9 & 7.9 & 7.9 & 7.5 & 7.5 & 7.5 & 7.5 \\
\hline Dig.threonine & $\mathrm{g} / \mathrm{kg}$ & 7.5 & 6.8 & 6.8 & 6.8 & 6.8 & 6.4 & 6.4 & 6.4 & 6.4 \\
\hline Dig.tryptophan & $\mathrm{g} / \mathrm{kg}$ & 2.37 & 2.30 & 2.30 & 2.30 & 2.30 & 2.17 & 2.17 & 2.17 & 2.17 \\
\hline Dig.isoleucine & $\mathrm{g} / \mathrm{kg}$ & 7.8 & 7.4 & 7.4 & 7.4 & 7.4 & 7.0 & 7.0 & 7.0 & 7.0 \\
\hline Dig.valine & $\mathrm{g} / \mathrm{kg}$ & 9.2 & 8.4 & 8.4 & 8.4 & 8.4 & 7.9 & 7.9 & 7.9 & 7.9 \\
\hline Dig.arginine & $\mathrm{g} / \mathrm{kg}$ & 12.5 & 12.0 & 12.0 & 12.0 & 12.0 & 11.3 & 11.3 & 11.3 & 11.3 \\
\hline Dig.glycine + serine & $\mathrm{g} / \mathrm{kg}$ & 16.3 & 15.7 & 15.7 & 15.7 & 15.7 & 14.9 & 14.9 & 14.9 & 14.9 \\
\hline Dig. P broiler & $\mathrm{g} / \mathrm{kg}$ & 4.4 & 3.8 & 3.8 & 3.9 & 3.9 & 2.8 & 2.8 & 2.8 & 2.8 \\
\hline
\end{tabular}




\section{Appendix 3 Amino acid ratios to lysine}

\begin{tabular}{|c|c|c|c|c|c|c|c|c|c|c|}
\hline & \multicolumn{2}{|c|}{ Starter diet } & \multicolumn{2}{|c|}{ Grower CP 205} & \multicolumn{2}{|c|}{ Grower CP 195} & \multicolumn{2}{|c|}{ Grower CP 185} & \multicolumn{2}{|c|}{ Grower CP 175} \\
\hline & $\mathrm{g} / \mathrm{kg}$ & $\begin{array}{l}\text { ratio } \\
\text { lysine }\end{array}$ & $\mathrm{g} / \mathrm{kg}$ & $\begin{array}{l}\text { ratio } \\
\text { lysine }\end{array}$ & $\mathrm{g} / \mathrm{kg}$ & $\begin{array}{l}\text { ratio } \\
\text { Iysine }\end{array}$ & $\mathrm{g} / \mathrm{kg}$ & $\begin{array}{l}\text { ratio } \\
\text { lysine }\end{array}$ & $\mathrm{g} / \mathrm{kg}$ & $\begin{array}{l}\text { ratio } \\
\text { lysine }\end{array}$ \\
\hline Lysine & 11.5 & $100 \%$ & 10.5 & $100 \%$ & 10.5 & $100 \%$ & 10.5 & $100 \%$ & 10.5 & $100 \%$ \\
\hline Methionine & 5.6 & $49 \%$ & 5 & $48 \%$ & 5.2 & $50 \%$ & 5.3 & $50 \%$ & 5.5 & $52 \%$ \\
\hline $\begin{array}{l}\text { Methionine+ } \\
\text { cysteine }\end{array}$ & 8.5 & $74 \%$ & 7.9 & $75 \%$ & 7.9 & $75 \%$ & 7.9 & $75 \%$ & 7.9 & $75 \%$ \\
\hline Threonine & 7.5 & $65 \%$ & 6.8 & $65 \%$ & 6.8 & $65 \%$ & 6.8 & $65 \%$ & 6.8 & $65 \%$ \\
\hline Tryptophan & 2.4 & $21 \%$ & 2.2 & $21 \%$ & 2.1 & $20 \%$ & 1.9 & $18 \%$ & 1.9 & $18 \%$ \\
\hline Arginine & 12.5 & $109 \%$ & 11.8 & $112 \%$ & 11.5 & $110 \%$ & 11.6 & $110 \%$ & 11.6 & $110 \%$ \\
\hline Valine & 8.5 & $74 \%$ & 8.4 & $80 \%$ & 8.4 & $80 \%$ & 8.4 & $80 \%$ & 8.4 & $80 \%$ \\
\hline Isoleucine & 7.8 & $68 \%$ & 7.4 & $70 \%$ & 7.3 & $70 \%$ & 7.4 & $70 \%$ & 7.4 & $70 \%$ \\
\hline Glycine+serine & 16.3 & $142 \%$ & 15.6 & $149 \%$ & 14.7 & $140 \%$ & 14.7 & $140 \%$ & 14.7 & $140 \%$ \\
\hline
\end{tabular}

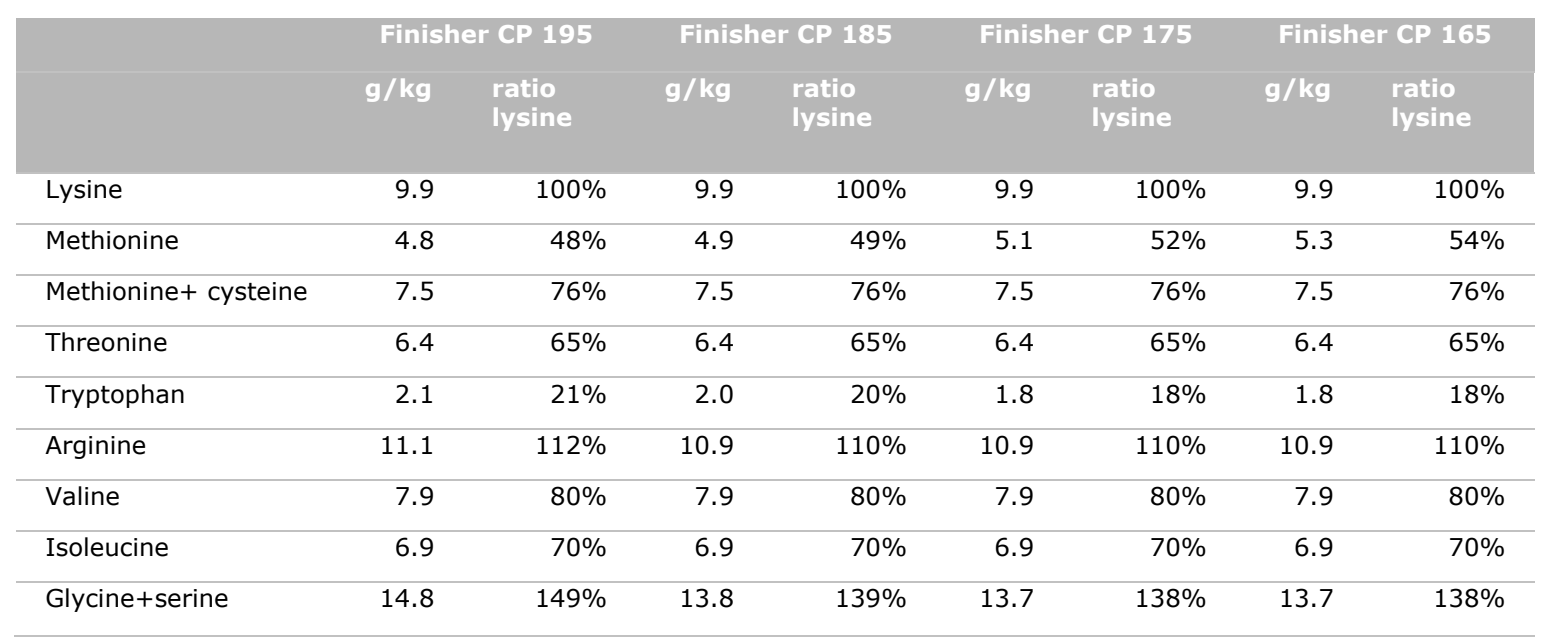




\section{Appendix 4 Overview of scores for foot- pad lesions}

Scorekaart voetzoollaesies vleeskuikens (versie 1.2)

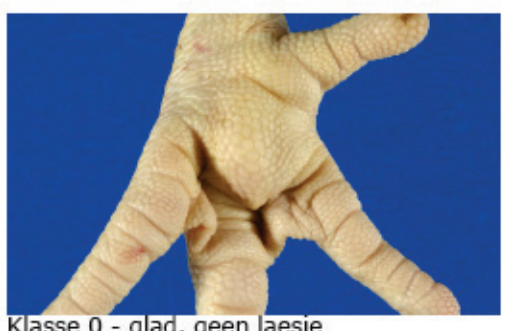

Klasse 0 - glad, geen laesie

Class 0 - smooth, no lesion

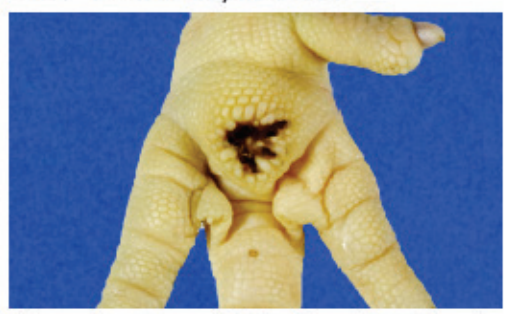

Klasse 1 - oppervlakkige laesie, verkleuring Class 1 - superficial lesion, discolouration

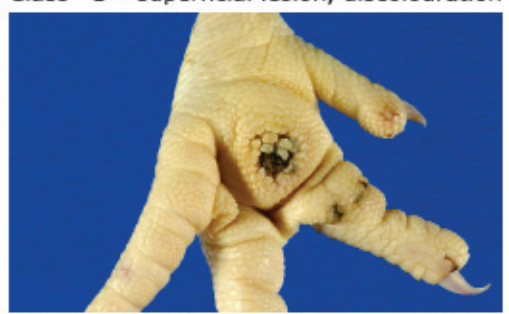

Klasse 2 - donkere papillen en ontsteking Class 2 - dark papillae and ulcer

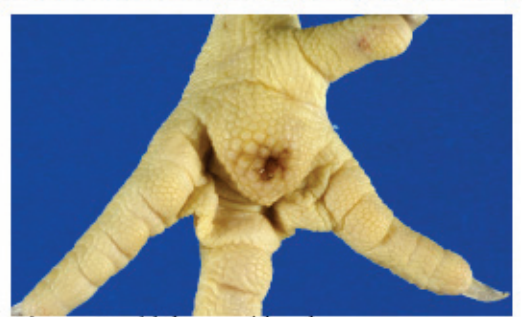

Klasse 0 - kleine verkleuring Class 0 - small discolouration

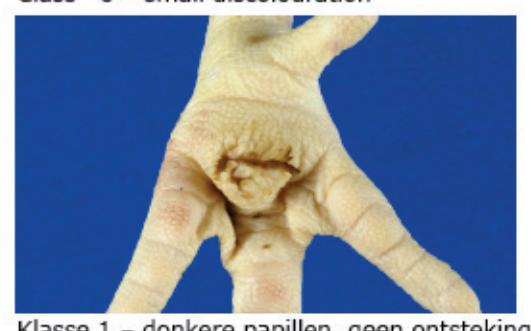

Klasse 1 - donkere papillen, geen ontsteking Class 1 - dark papillae, no ulceration

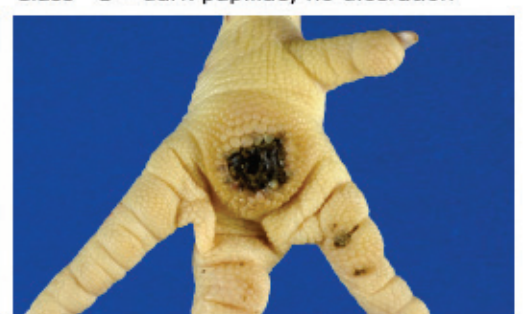

Klasse 2 - ontsteking bedekt met korst Class 2 - ulcer covered by crust

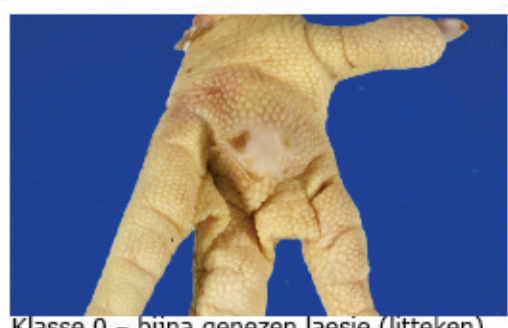

Klasse 0 - bijna genezen laesie (litteken)

Class 0 - almost healed lesion, scar

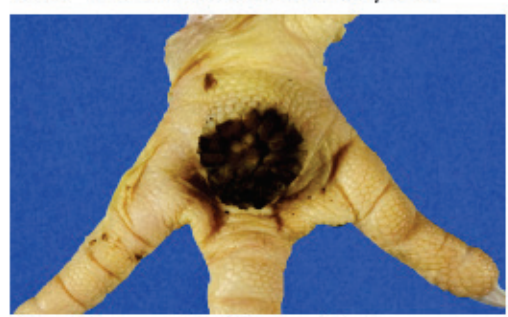

Klasse 1 - aanzienlijke verkleuring Class 1 - substantial discolouration

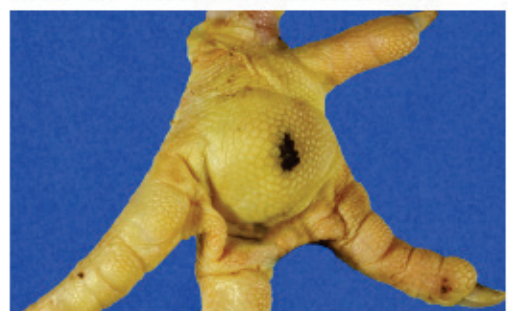

Klasse 2 - ontsteking/bumble foot, gezwollen Class 2 - abcess/bumble foot swollen 


\section{Appendix 5 Relative differences between calculated and analysed amino acid contents of the grower and finisher diets}

Table A5.1 Relative differences (in \%) between calculated and analysed amino acids contents of the grower and finisher diets

\begin{tabular}{|c|c|c|c|c|c|c|c|c|}
\hline & \multicolumn{4}{|c|}{ Grower diets } & \multicolumn{4}{|c|}{ Finisher diets } \\
\hline & Control CP & CP-1\% & CP-2\% & CP-3\% & Control CP & CP-1\% & CP-2\% & CP-3\% \\
\hline LYS & -2.5 & -0.9 & -0.9 & -1.7 & -3.6 & -2.7 & -3.6 & -0.9 \\
\hline METH & -5.6 & -5.5 & -3.6 & -5.2 & -3.9 & -3.8 & -5.6 & -3.6 \\
\hline CYS & -5.7 & -5.9 & -3.1 & 0.0 & -2.9 & -3.0 & -3.2 & 0.0 \\
\hline THR & -1.2 & 1.3 & -1.3 & -1.3 & -2.6 & -2.6 & -2.7 & -1.4 \\
\hline \multicolumn{9}{|l|}{ TRP } \\
\hline ILE & 2.4 & 2.4 & 2.4 & -1.2 & 1.3 & 2.6 & 0.0 & 1.3 \\
\hline ARG & 0.0 & 3.1 & 2.4 & 0.8 & -0.8 & 0.8 & 0.0 & 0.8 \\
\hline FEN & 2.0 & 4.3 & 3.6 & 2.6 & 1.1 & 3.4 & 2.5 & 2.7 \\
\hline HIS & -3.8 & 0.0 & -2.2 & -2.4 & -6.0 & -2.1 & -2.3 & -5.0 \\
\hline LEU & -0.6 & 2.7 & 2.2 & 0.8 & -3.3 & 2.1 & 0.0 & 2.4 \\
\hline \multicolumn{9}{|l|}{ TYR } \\
\hline VAL & 2.1 & 2.1 & -1.0 & -2.1 & 2.2 & 0.0 & -1.1 & -1.1 \\
\hline ALA & -0.2 & 3.0 & 2.6 & 2.1 & -3.5 & 1.8 & 0.8 & 3.3 \\
\hline ASP & -0.2 & 2.1 & 0.4 & -0.5 & -2.1 & 1.6 & 1.0 & -1.6 \\
\hline GLU & -0.2 & -0.3 & -2.0 & -2.5 & -1.1 & -1.8 & -3.3 & -2.4 \\
\hline GLY & 0.6 & 10.2 & 9.1 & 7.2 & -2.0 & 10.6 & 11.0 & 11.8 \\
\hline PRO & -0.2 & 0.7 & -1.1 & 0.2 & -1.6 & -2.1 & -2.4 & 0.0 \\
\hline SER & -0.4 & 1.6 & -0.5 & 2.4 & -1.4 & 0.6 & 0.4 & 1.5 \\
\hline
\end{tabular}




\section{Appendix 6 Performance results $0-11$ days}

Table A6.1 Performance results starter phase (0 - 11 days)

\begin{tabular}{lrrrrrr} 
& Control CP & \multicolumn{1}{c}{ CP-1\% } & CP-2\% & CP-3\% & F-prob & LSD \\
Live weight $(\mathrm{g})$ & 324 & 323 & 323 & 321 & 0.656 & 4.31 \\
\hline Growth $(\mathrm{g})$ & 287 & 285 & 285 & 284 & 0.656 & 4.31 \\
\hline Growth $(\mathrm{g} / \mathrm{d})$ & 26.1 & 26.0 & 25.9 & 25.8 & 0.656 & 0.39 \\
\hline Mortality $(\%)$ & 0.0 & 0.9 & 0.0 & 1.4 & 0.401 & 1.93 \\
\hline FCR & 1.101 & 1.106 & 1.106 & 1.107 & 0.851 & 0.0158 \\
\hline CP conversion & 0.2378 & 0.2388 & 0.2389 & 0.2402 & 0.629 & 0.00364 \\
\hline Feed intake $(\mathrm{g})$ & 28.7 & 28.7 & 28.7 & 28.7 & &
\end{tabular}




\section{Appendix 7 Effect diet composition on carbon footprint diet}

\begin{tabular}{|c|c|c|c|c|c|c|c|c|c|c|c|c|c|c|c|c|c|c|c|c|}
\hline & & \multicolumn{9}{|c|}{ Diet composition } & \multicolumn{3}{|l|}{ CFP } & \multicolumn{6}{|c|}{ CFP per ingredient $\left(\mathrm{g} / \mathrm{CO}_{2}-\mathrm{eq} / \mathrm{kg}\right)$} & \multirow[b]{2}{*}{$\mathrm{CP}-3 \%$} \\
\hline & & Starter & $\begin{array}{c}\text { Control } \\
\text { CP }\end{array}$ & CP-1\% & $C P-2 \%$ & CP-3\% & $\begin{array}{c}\text { Control } \\
\text { CP }\end{array}$ & CP-1\% & CP-2\% & CP-3\% & $\begin{array}{l}\mathrm{gCO}_{2-} \\
\mathrm{eq} / \mathrm{kg}\end{array}$ & Starter & $\begin{array}{c}\text { Control } \\
\text { CP }\end{array}$ & CP-1\% & CP-2\% & CP-3\% & $\begin{array}{c}\text { Control } \\
\text { CP }\end{array}$ & CP-1\% & CP-2\% & \\
\hline Wheat & $\%$ & 30.87 & 37.29 & 30.00 & 30.00 & 30.00 & 39.64 & 30.00 & 30.00 & 30.29 & 399 & 123 & 149 & 120 & 120 & 120 & 158 & 120 & 120 & 121 \\
\hline Corn & $\%$ & 25.00 & 18.80 & 29.04 & 32.75 & 36.51 & 20.56 & 33.02 & 36.49 & 40.00 & 604 & 151 & 114 & 175 & 198 & 221 & 124 & 199 & 220 & 242 \\
\hline Soybean meal HiPro & $\%$ & 30.47 & 27.34 & 24.84 & 21.07 & 17.30 & 24.99 & 22.55 & 18.41 & 14.62 & 649 & 198 & 177 & 161 & 137 & 112 & 162 & 146 & 119 & 95 \\
\hline Rapeseed meal 00 & $\%$ & 3.00 & 5.00 & 4.96 & 5.00 & 5.00 & 4.28 & 4.40 & 5.00 & 5.00 & 481 & 14 & 24 & 24 & 24 & 24 & 21 & 21 & 24 & 24 \\
\hline Palm oil crude & $\%$ & 1.54 & 2.71 & 2.45 & 2.19 & 1.51 & 2.51 & 2.25 & 1.68 & 1.01 & 1591 & 25 & 43 & 39 & 35 & 24 & 40 & 36 & 27 & 16 \\
\hline Soya lecithin & $\%$ & 1.00 & 1.00 & 1.00 & 1.00 & 1.00 & 1.00 & 1.00 & 1.00 & 1.00 & 1591 & 16 & 16 & 16 & 16 & 16 & 16 & 16 & 16 & 16 \\
\hline Soya oil & $\%$ & 0.92 & 1.51 & 0.87 & 0.50 & 0.50 & 1.22 & 0.50 & 0.50 & 0.50 & 1591 & 15 & 24 & 14 & 8 & 8 & 19 & 8 & 8 & 8 \\
\hline Lauric fatty acids & $\%$ & 0.50 & 0.50 & 0.50 & 0.50 & 0.50 & 0.50 & 0.50 & 0.50 & 0.50 & 1591 & 8 & 8 & 8 & 8 & 8 & 8 & 8 & 8 & 8 \\
\hline Limestone & $\%$ & 0.25 & -- & -- & -- & -- & 0.25 & 0.25 & 0.25 & 0.26 & 19 & 0 & 0 & 0 & 0 & 0 & 0 & 0 & 0 & 0 \\
\hline L-Lysine $\mathrm{HCl}$ & $\%$ & 0.22 & 0.16 & 0.24 & 0.36 & 0.48 & 0.16 & 0.24 & 0.36 & 0.47 & 6030 & 13 & 9 & 14 & 21 & 29 & 10 & 14 & 22 & 29 \\
\hline Sodiumbicarbonate & $\%$ & 0.28 & 0.21 & 0.25 & 0.31 & 0.39 & 0.24 & 0.28 & 0.34 & 0.41 & 1050 & 3 & 2 & 3 & 3 & 4 & 3 & 3 & 4 & 4 \\
\hline DL-methionine & $\%$ & 0.28 & 0.23 & 0.25 & 0.29 & 0.32 & 0.21 & 0.24 & 0.27 & 0.31 & 5490 & 15 & 12 & 14 & 16 & 18 & 12 & 13 & 15 & 17 \\
\hline Sodium chloride & $\%$ & 0.11 & 0.13 & 0.10 & 0.06 & & 0.12 & 0.09 & 0.05 & & 180 & 0 & 0 & 0 & 0 & 0 & 0 & 0 & 0 & 0 \\
\hline L-threonine & $\%$ & 0.09 & 0.05 & 0.09 & 0.14 & 0.19 & 0.05 & 0.08 & 0.14 & 0.19 & 16978 & 15 & 8 & 15 & 24 & 33 & 8 & 14 & 23 & 32 \\
\hline L-Valine 98 & $\%$ & 0.07 & 0.02 & 0.07 & 0.14 & 0.21 & 0.02 & 0.07 & 0.14 & 0.20 & 9500 & 7 & 2 & 7 & 13 & 19 & 2 & 6 & 13 & 19 \\
\hline Xylanase $6,25 \%$ & $\%$ & 0.10 & 0.10 & 0.10 & 0.10 & 0.10 & 0.10 & 0.10 & 0.10 & 0.10 & 4999 & 5 & 5 & 5 & 5 & 5 & 5 & 5 & 5 & 5 \\
\hline Phyzyme XP 5000L & $\%$ & 0.01 & 0.01 & 0.01 & 0.01 & 0.01 & 0.01 & 0.01 & 0.01 & 0.01 & 4999 & 0 & 0 & 0 & 0 & 0 & 0 & 0 & 0 & 0 \\
\hline Oat hulls & $\%$ & 2.00 & 2.00 & 2.00 & 2.00 & 2.00 & 2.00 & 2.00 & 2.00 & 2.00 & 478 & 10 & 10 & 10 & 10 & 10 & 10 & 10 & 10 & 10 \\
\hline Monocalciumphosphate & $\%$ & 0.99 & 0.66 & 0.69 & 0.76 & 0.82 & 0.15 & 0.19 & 0.22 & 0.26 & 4999 & 49 & 33 & 35 & 38 & 41 & 7 & 9 & 11 & 13 \\
\hline L-Arginine & $\%$ & -- & -- & 0.08 & 0.19 & 0.30 & -- & 0.08 & 0.19 & 0.30 & 9500 & 0 & 0 & 8 & 18 & 28 & 0 & 8 & 18 & 28 \\
\hline L-Isoleucine & $\%$ & -- & -- & 0.04 & 0.11 & 0.18 & -- & 0.04 & 0.11 & 0.18 & 9500 & 0 & 0 & 4 & 10 & 17 & 0 & 4 & 11 & 17 \\
\hline L-Glycine & $\%$ & -- & -- & 0.09 & 0.21 & 0.34 & -- & 0.09 & 0.22 & 0.34 & 9500 & 0 & 0 & 8 & 20 & 32 & 0 & 8 & 20 & 32 \\
\hline L-Tryptophan & $\%$ & -- & -- & 0.02 & 0.04 & 0.06 & -- & 0.02 & 0.04 & 0.06 & 9500 & 0 & 0 & 2 & 4 & 6 & 0 & 2 & 4 & 6 \\
\hline VM VLK 20-40 & $\%$ & 2.00 & 2.00 & 2.00 & 2.00 & 2.00 & -- & -- & -- & -- & 4999 & 100 & 100 & 100 & 100 & 100 & 0 & 0 & 0 & 0 \\
\hline VM VLK 0-20 dgn & $\%$ & -- & -- & -- & -- & -- & 2.00 & 2.00 & 2.00 & 2.00 & 4999 & 0 & 0 & 0 & 0 & 0 & 100 & 100 & 100 & 100 \\
\hline \multirow[t]{2}{*}{ VM Maxiban 0,3\% } & $\%$ & 0.30 & 0.30 & 0.30 & 0.30 & 0.30 & & & & & 4999 & 15 & 15 & 15 & 15 & 15 & 0 & 0 & 0 & 0 \\
\hline & & & & & & & & & & Tota & & 83 & 752 & 796 & 842 & 888 & 704 & 752 & 797 & 841 \\
\hline
\end{tabular}



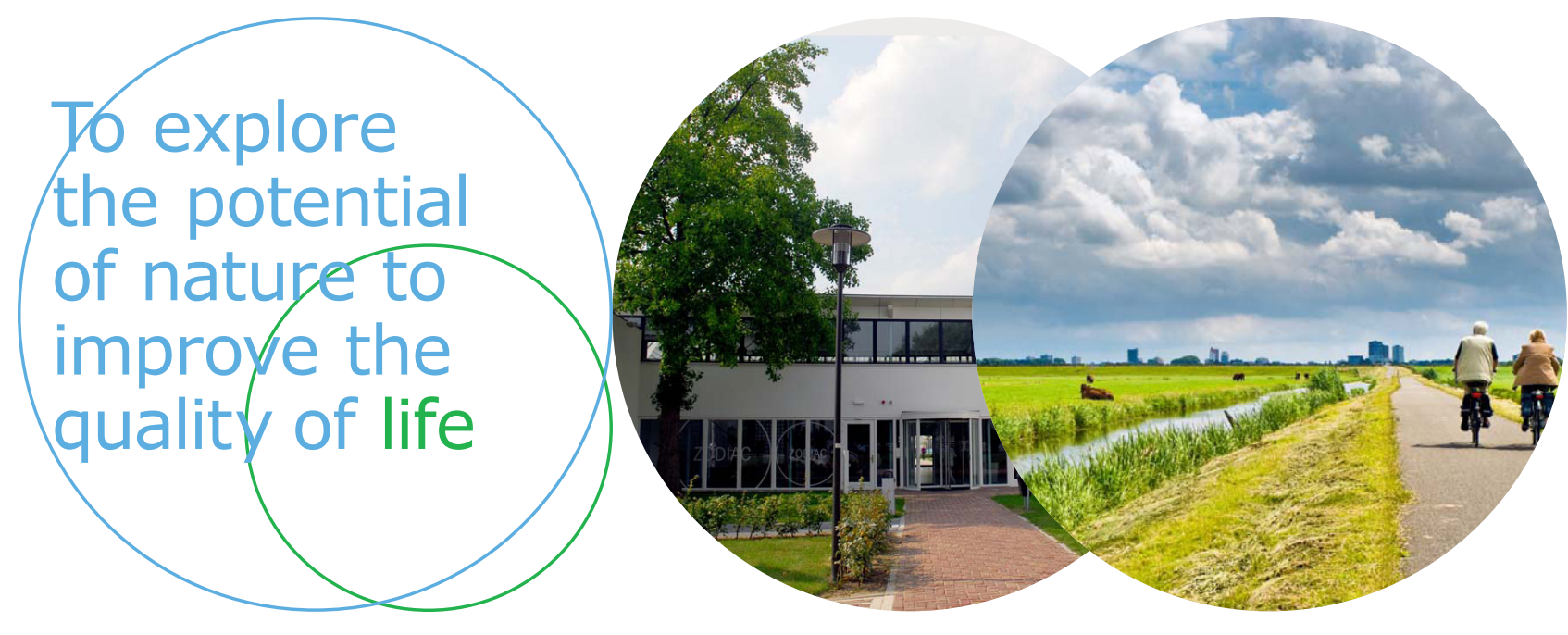

Wageningen Livestock Research P.O. Box 338

6700 AH Wageningen

The Netherlands

T +31 (0)317483953

E info.livestockresearch@wur.nl www.wur.nl/livestock-research

Wageningen Livestock Research creates science based solutions for a sustainable and profitable livestock sector. Together with our clients, we integrate scientific knowledge and practical experience to develop livestock concepts for future generations.

Wageningen Livestock Research is part of Wageningen University \& Research. Together we work on the mission: 'To explore the potential of nature to improve the quality of life'. A staff of 6,500 and 10,000 students from over 100 countries are working worldwide in the domain of healthy food and living environment for governments and the business community-at-large. The strength of Wageningen University \& Research lies in its ability to join the forces of specialised research institutes and the university. It also lies in the combined efforts of the various fields of natural and social sciences. This union of expertise leads to scientific breakthroughs that can quickly be put into practice and be incorporated into education. This is the Wageningen Approach. 